\title{
«Employment protection reform in European labor markets: the collective bargaining regime matters »
}

\author{
$\underline{\text { Auteurs }}$ \\ Francesco De Palma, Yann Thommen \\ Document de Travail $n^{\circ} 2019-16$
}

Mai 2019

Bureau d'Économie

Théorique et Appliquée

BETA

www.beta-umr7522.fr

@beta_economics

Contact :

jaoulgrammare@beta-cnrs.unistra.fr 


\title{
Employment protection reform in European labor markets: the collective bargaining regime matters ${ }^{\text {th }}$
}

\author{
Francesco De Palma \\ Université de Strasbourg, Université de Lorraine, CNRS, BETA UMR 7522, F-67000, Strasbourg, France \\ Yann Thommen* \\ Université de Strasbourg, Université de Lorraine, CNRS, BETA UMR 7522, F-67000, Strasbourg, France
}

\begin{abstract}
Policy advisers repeatedly call on Western European countries to reform their employment protection legislation (EPL) by adopting layoff taxes to finance unemployment insurance (UI). This new design, partly based on the existing "experience-rating" (ER) system in the U.S., would induce firms to internalize layoff fiscal costs and hence reduce unemployment. Its success remains uncertain in economies with a collective wage-setting system, as in many Western European countries. Using a matching model with endogenous job destruction, we provide an ex-ante evaluation of this policy reform's effects on labor market outcomes in a firm-level bargaining economy and a sector-level bargaining one. Using numerical exercises, we show that compared to a scenario of a simple increase in EPL stringency, the implementation of an ER system results in a decrease in unemployment under both bargaining regimes. Because of the possibility for firms to adjust most terms and conditions of employment (including wage) in decentralized negotiations, juxtaposing the ER system with the existing EPL yields the best labor market performance under a firm-level bargaining regime. The lack of internal flexibility in sector-level bargaining calls for accompanying the implementation of the ER with a relaxation of the existing EPL's stringency. Lastly, we show that in industries with a turbulent economic environment, accompanying the introduction of ER while reducing the existing EPL's strictness is recommended.
\end{abstract}

Keywords: Search and matching models, Collective bargaining, Experience rating, Employment protection JEL classification: E10, J48, J50, J60

\section{Introduction}

The vast majority of Western European countries are characterized by the coexistence of an unemployment insurance system (henceforth, UI) and of an employment protection legislation (henceforth, EPL). These two institutions are distinct and uncoordinated. The existing national EPLs are criticized for being too rigorous and creating uncertainty, leading to exacebated segmentation ${ }^{1}$, slow job reallocation ${ }^{2}$ and a feeling of insecurity for workers ${ }^{3}$. When they lose their job, unemployed workers receive unemployment benefits according to an insurance scheme financed by employee-employer payroll taxes (MISSOC Database). These payroll taxes increase the wage burden, have a disincentive effect on employment, and do not encourage employers to internalize the social costs of labor turnover. This leads to a double incentive to destroy jobs (Cahuc et al., 2014). Blanchard and Tirole (2008)

\footnotetext{
${ }^{4}$ We would like to thank Bernardo Fanfani (University of Torino) for his helpful discussion during the IAAEU workshop on Labour Economics 2018. The paper also benefited from the comments of the participants at the Labour market workshop at the Central Bank of Luxembourg, the 30th European Association of Labour Economist (EALE) 2018, the 1st CESifo EconPol Europe PhD Workshop 2018 and the 2nd ERMEES Macroeconomics Workshop 2017. We also thank François Fontaine (PSE), Anne Bucher, Mathieu Lefebvre and Thierry Betti (University of Strasbourg) for their insightful comments.

${ }^{*}$ Corresponding author. E-mail address: ythommen@unistra.fr.

${ }^{1}$ See Cazes and Nesporova (2003), OECD (2013)

${ }^{2}$ See Blanchard and Portugal (2001), Boeri and Garibaldi (2009), Martin and Scarpetta (2012) and Bassanini and Garnero (2013)

${ }^{3}$ See Postel-Vinay and Saint-Martin (2004), Clark and Postel-Vinay (2009)
} 
propose an in-depth revision by combining EPL and UI in a coherent scheme, consisting in funding unemployment benefits through layoff taxes. Their proposal is inspired by the experience-rating system ${ }^{4}$ (henceforth, ER) set up in the United States (U.S.), which partly internalizes the fiscal cost of job destruction. Indeed, even if a layoff is efficient at the individual level (firm-worker pair), it generates a fiscal externality since the newly unemployed worker will receive unemployment benefits. If the UI financing is pooled via a payroll tax common to all firms, then a firm that dismisses a worker decreases its contribution to the UI fund even though it increases the latter's financial burden. The firms that do not lay off any worker bear the additional fiscal cost of unemployment. The main features of an ER implementation would be taxing firms' layoffs proportionally to the expected cost of the new unemployed for the UI, while accompanying this reform by reducing existing administrative and judicial costs related to dismissals. Policy advisers have repeatedly called for such a system, which would play a job protection role by taxing redundancies while making the financing of UI fairer and less burdensome in terms of labor cost ${ }^{5}$.

This paper aims to assess the effects of this UI-EPL scheme reform based on ER, focusing on its potential interaction with the well established collective bargaining systems in European economies.

Indeed, ER's effects on U.S. labor market outcomes are well established, characterized chiefly by decreased labor turnover. The theoretical basis for this was developed in a seminal paper by Feldstein (1976), showing that no ER used in the financing of UI benefits leads to inefficiently high levels of labor turnover. Topel (1983), Anderson and Meyer (1994) and Woodbury et al. (2004) have empirically shown that reducing the share of pooling in the financing of UI reduces the number of layoffs. In their study of a "natural experiment", Washington State's 1985 forced transition from a common tax rate system to an experience-rated tax system, Anderson and Meyer (2000) show a reduction in the frequency of layoffs, but also a decline in wages in industries that frequently used turnover before the reform. In a recent work, Ratner (2013) theoretically demonstrated that moving closer to a complete experience-rated system would reduce the number of job creations and destructions; in other words, more ER helps to stabilize employment. He then empirically tested these theoretical predictions using US data for the 2001-2010 period and concluded that increasing the employer's individual share of UI funding by $5 \%$ would reduce the number of job creations by $1.5 \%$ and the number of job destructions by $2 \%$.

However, ER's potential effects on the European labor market seem uncertain, due to the presence of intertwining channels of influence, particularly through the collective bargaining system.

First, it would modify the EPL. Theoretical insights show that modifying of EPL strictness has an ambiguous effect on employment and unemployment stocks, as it affects hiring and separation in the same way. The empirical literature has failed to reach a conclusive consensus about the EPL's effect on employment and unemployment stock levels, in particular because its effect on labor market flows (labor turnover and job turnover) remains ambiguous (Boeri and Van Ours, 2013). The fact that empirical studies have not confirmed theoretical results on the labor market flows is explained by the combination of EPL with other labor market institutions, particularly wage setting institutions (Bertola and Rogerson, 1997, Nickell and Layard, 1999, Belot and Van Ours, 2004, Boeri, 2010). However, unions and collective bargaining tend to compress the wage structure ${ }^{6}$, affecting the capacity of price-adjustment and hence increasing job destruction, contrary to a strengthening of EPL and also against the objective of an ER system. Yet, unlike in the U.S., where ER applies in a labor market with decentralized wage-bargaining, in Western European economies it would interact with well-established collective bargaining ${ }^{7}$. Although there is a trend towards decentralization, many agreements are still bargained at the sectoral level ${ }^{8}$ (Andolfatto et al., 2016). More aptly, many countries adopt a two-tier bargaining scheme, with firm-level bargaining supplementing national or sectoral agreements and taking the agreement established at the multi-employer level as a floor. However, this scheme fails in its two main objectives: strengthening macroeconomic stability (characteristic of centralized negotiations) and better aligning wages with productivity (characteristic of decentralized negotia-

\footnotetext{
${ }^{4}$ For a description of the U.S. experience-rating, see Fath and Fuest (2005a) and section 2. in Ratner (2013).

${ }^{5}$ Most recently, in the press: Le bonus-malus : «Une juste responsabilisation des entreprises », Le Monde, November 1, 2017. See also German Council of Economic Experts (2003), European Commission (2004).

${ }^{6}$ Wage dispersion is lower in economies with more centralized bargaining structures. See OECD (1997), Aidt and Tzannatos (2002), Rycx (2003), OECD $(2004,2018)$.

${ }^{7}$ See Figure 1. in Section 2.

${ }^{8}$ See Table 1. in Section 2.
} 
tions)(Boeri, 2015).Indeed, the features of firm-level bargaining partly differ from those of sector-level bargaining: negotiations at the sectoral level take less heed of firm-specific needs than decentralized negotiations within the firm. In particular, labor productivity (Gnocchi et al., 2015, OECD, 2016); employment conditions (wages, hours worked, among others) are less flexible in labor markets with more centralized levels (national/sectoral/regional level) (Druant et al., 2012, Boeri, 2014, Izquierdo et al., 2017).If wages fail to adjust to changes in job-specific productivity, the theory predicts a higher unemployment rate due to more job destruction and less hiring (Jimeno and Thomas, 2013). Ronchi and di Mauro (2017) support these theoretical insights and empirical observations by showing that wage negotiation set-ups have shaped firms' responses to the Great Recession in the EU: more centralized bargaining systems have led to stronger downward wage rigidity, more job destruction and falls in profits compared to decentralized bargaining systems.

Second, as these features influence labor market flows, they affect the rate and duration of unemployment ${ }^{9}$. However, financing based on experience-rated layoff taxes depends on the expected duration of unemployment periods; the greater the unemployment duration or rate, the higher the experience-rated layoff tax will have to be, at a given degree of individualization in UI financing. Thus, the adverse effects of an excessively strict EPL on labor market flows will require an arbitrage between the requested level of experience-rated layoff taxes and the desired degree of individualization in the financing of UI.

Third, funding UI via layoffs taxes implies payroll subsidies. The impacts of these subsidies on wage levels may differ depending on whether they are set individually within the firm or collectively at the sectoral level. However, wage response can be decisive as it would in turn affect the labor market flows, which consequently would affect the level of required taxes and ultimately the effect of the new system on labor market outcomes.

Beyond studies on the specific U.S. case, some effects of the ER system and its interaction with structural elements of the labor market have been studied in the literature. Several authors have in particular addressed forms of ER implementation. Fath and Fuest (2005b) compared an experience-rated system of layoff costs with a system of severance payment, by assessing their respective effects on employment and welfare in an efficiency wage model with endogenous worker monitoring. The economic environment that they model generates an inefficiently high labor turnover. Their results show that the experience-rated system is preferable because of its positive effects on employment and welfare, unlike the severance payments, which decrease employment and may fail in reducing labor turnover; this is because the ER makes it possible to lower payroll taxes and does not require a monetary transfer from the firm to the worker - meaning that the latter has no incentive to reduce his effort. These results are close to those of Albrecht and Vroman (1999), which indicated that funding UI by taxing firms in proportion to their layoffs leads to less unemployment, less shirking, and higher outputs than a payroll-tax system. Fath and Fuest (2005c) performed the same type of work but using an implicit-contract model. They show that experience-rating designed as an additional layoff tax has an ambiguous effect on long-term employment because it increases the separation-decision cost while reducing payroll taxes, but it unambiguously increases welfare. Although all these results support the introduction of an ER system, Mongrain and Roberts (2005) nuance them by showing that setting too high a degree of experience rating may decrease workers' insurance coverage (and by extension, their welfare) because firms may reduce their severance payments by more than the UI benefit. Albertini (2011) deepens the analysis by using a DSGE business cycle model with matching frictions and endogenous job destruction and also by refining the modeling of the ER system (statutory payroll tax rates based on the reserveratio method, very close to the U.S. system). He compares the ER system to a layoff tax financing unemployment benefits. Both systems effectively stabilize short-run fluctuations of the labor market and reduce unemployment, but only the system with layoff taxes discourages firms from creating jobs and cuts their profits.

Our paper is closer to the literature that attempts to analyze the effects of the introduction of ER in a European style labor market. Cahuc and Malherbet (2004)use an equilibrium search and matching model with a balanced budget constraint for the UI to assess how ER interacts with temporary jobs, EPL and minimum wage. Their results suggest that ER via layoff taxes to finance UI is recommendable in a labor market with rigid institutions: it reduces the unemployment rate for low-skilled workers and improves their welfare in a labor market with a high minimum

\footnotetext{
${ }^{9}$ During the 2014-2017 period, the average unemployment duration for individuals aged 25-54 was 7.1 months in the U.S. and 15.2 months in the EU-16 countries (OECD).
} 
wage, a strict EPL and a dual labor market. These results on low-skilled workers are questioned by Charlot and Malherbet (2010): making layoff taxes proportional to the expected cost of UI may be adverse for low-skilled workers whose average duration of unemployment is longermaking layoff taxes proportional to the expected cost of UI may have adverse effects for low-skilled workers whose average duration of unemployment is longer. They conclude that these can be counterbalanced with an adequate degree of substitution between experience-rating and the traditional EPL existing in European labor markets. In addition, in the long run, the effect will probably be positive thanks to an incentive to educate. L'Haridon and Malherbet (2009) use a somewhat similar framework (especially, a restrictive EPL) extended with aggregate macroeconomic shocks; they do not focus only on the steady state, but observe the dynamic effects of ER. Their calibration on French data helps them to conclude that the implementation of ER (by substitution with the existing EPL) decreases the necessary budget for UI, increases production, decreases unemployment and the variability of aggregate employment. All these papers model either non-bargained wages or wages bargained individually between workers and firms. They ignore the importance of trade unions and collective bargaining in European countries. This is adressed by Baumann and Stähler (2008), who analyze the impact of unions on the success of an ER system in Europe. They deviate from the standard Nash bargaining model by modeling an insider-dominated monopoly workers' union that sets wages; the union sets the wage unilaterally by maximizing the gain in employment net of unemployment, taking into account firm reaction (the change in the productivity threshold). They conclude that the interaction between ER and this wage-setting process may lead to an increase in unemployment. They explain their result by the following cumulative effects: the classical effect of the EPL on labor turnover (ambiguous effect on unemployment), excessively high wage claims from the insider-dominated union, since lower labor turnover reduces its marginal utility loss when raising the wage, which reduces firms' incentives for job creation.

We depart from the latter paper by not assuming any particular union's objective or any particular model of collective bargaining, based on the observation that social dialogue regimes are heterogeneous in Europe (Terraz and Jaoul-Grammare, 2012, Andolfatto et al., 2016). Besides, the assumption of an insider-dominated monopoly union is strong and may drive the results, especially through high wage demands. In this paper, we settle for the modeling of a situation in which conditions are set under sectoral agreements that cannot be renegotiated with lower standards for the employee at the firm level, because of the "favorability" principle anchored in law. This assumption implies a more compressed wage structure compared to a fully decentralized bargaining within the firm. We think this is an explicit and common feature, which is not related to the political choices of unions, and is as such a reasonable assumption.

To achieve this, we adopt a search-and-matching labor market framework (Mortensen and Pissarides, 1994, 1999) with endogenous job destruction, composed of one industry (sector) with two alternative wage bargaining regimes, as in Jimeno and Thomas (2013): (1) A firm-level bargaining that results in wages responding to firmspecific productivity. (2) A sector-level bargaining that sets a common wage for all firms in the sector, taking into account sector-wide average productivity. Furthermore, we model a restrictive EPL composed of tax and other costs related to a firm-initiated layoff (trial costs, administrative procedures) and a balanced UI budget that can be financed both by a standard payroll tax and/or by layoff taxes proportional to the average duration of unemployment, in line with L'Haridon and Malherbet (2009). This framework allows us to compare labor market outcomes under firm-level and sector-level bargaining following the implementation of an UI experience-rating funding based on layoff taxes. In order to highlight the interaction between collective bargaining regimes and the strictness of job protection, we consider 3 reform scenarios: (1) the ER tax that funds the UI is implemented without a review of the current EPL (addition scenario). (2) the ER tax that funds the UI is implemented with a relaxation of the current EPL (as advocated by Blanchard and Tirole (2003)) (substitution scenario). (3) no ER tax is implemented, only an increase in the existing EPL's stringency ('EPL only' scenario).

Numerical exercises are performed to draw conclusions from the model. The calibration is based on data from the French labor market, which is fairly representative of Western European countries in terms of collective bargaining structure and EPL.

Our research yields three main findings. First, introducing an ER layoff tax to finance the UI reduces unemployment, regardless of the reform design or the bargaining regime. Indeed, implementing ER has two direct effects: (i) an increase in the EPL's strictness (only in the addition scenario) and (ii) a decrease in the pooled share in the 
financing of UI, i.e. of the payroll tax common to all firms. These two effects impact jobs' (expected) profit for firms and in the process reduce job destruction (by encouraging labor hoarding) while incentivizing job creation. Second, the magnitude of ER effects on labor market outcomes depends on the design and bargaining regime. In an economy based on a sectoral bargaining regime, it is recommended to adopt ER by relaxing the existing EPL's strictness (substitution scenario). On the other hand, in an economy with firm-level negotiations, it is advisable to adopt ER without relaxing the existing EPL's strictness (addition scenario). This result is essentially based on the impossibility of adjusting wages to the productivity of each firm and hence the possibility of downward wage adjustments in response to an economic shock. Indeed, in the sector-level bargaining regime, wage rigidity exacerbates the effects of changes in separation costs. Lastly, we show that the effects of the reform on unemployment vary with the level of economic turbulence. In industries where shocks are frequent, it is preferable to adopt a substitution scenario. This applies even more to an economy with sectoral negotiations: when shocks are more frequent incentives to create jobs are much more negatively affected in the sector-level bargaining regime than in the firm-level bargaining regime.

The paper proceeds as follows. Section 2 illustrates the importance of labor market institutions in Western European countries. Section 3 outlines the model. Section 4 implements a quantitative approach to provide an ex-ante evaluation of the ER-system implementation and formulate recommendations. Section 5 concludes.

\section{Illustrative overview}

The figures in this section are used to support the paper's motivations and general argument, as well as to support the assumptions made in the model.

\subsection{The collective bargaining regimes}

More than trade union density rate, the indicator that reflects the importance (and power) of unions is the coverage rate of collective bargaining. It represents the percentage of workers whose contract is framed by a collective agreement out of the total number of workers with a right to bargain. As shown in Figure 1., the collective bargaining coverage rate in Western European countries is much higher than the average rate for OECD countries, and, to an even greater extent, than for the U.S.. The influence of the unions and collective bargaining is therefore strong.

Figure 1: Collective bargaining coverage rate in 2016

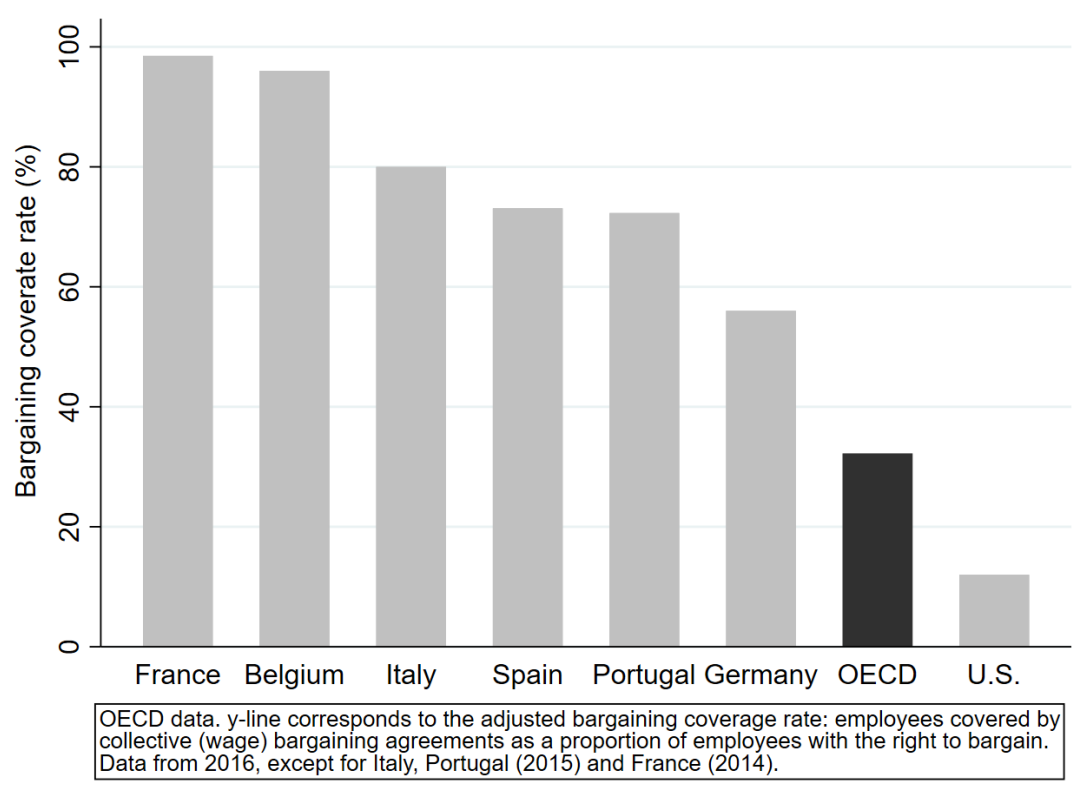


In order to complement the description of the collective bargaining regimes, we provide information about the level at which agreements/contracts are negotiated: firm/plant-level, sectoral/industry-level or national/centrallevel. Even though within the same country, wage bargaining occurs at different levels (generally, the social partners or the state set a minimum wage as well as boundaries at a centralized level, within which is possible to negotiate at a more decentralized level), it is possible to define an actual level at which wage bargaining takes place, taking into account the scope of additional enterprise bargaining, the articulation of enterprise bargaining, the possibility of exemptions and the existence of general opening clauses in collective agreements. These levels are reported in Table 1. for the Western European countries and the U.S. Again, a clear difference exists between the Western European countries and the U.S. Although European economies are not entirely homogeneous, collective wage bargaining in Europe takes place mainly at the sectoral level. On the contrary, in the U.S., it takes place mainly at the firm level. The importance of sectoral negotiations is confirmed by the Table 2 . It shows that the sectoral organization of employment relations is strongly implemented in European economies, while it does not exist in the U.S.

Table 1: The actual level at which wage bargaining takes place (1 to 5)

\begin{tabular}{cccccccc}
\hline & Belgium & France & Germany & Italy & Portugal & Spain & U.S. \\
\hline $1990-91$ & 4.2 & 3.1 & 3.6 & 2.1 & 4.8 & 3.5 & 1.0 \\
$2000-01$ & 4.2 & 2.7 & 3.1 & 3.2 & 3.8 & 3.3 & 1.0 \\
$2007-08$ & 4.1 & 2.3 & 2.9 & 3.1 & 3.8 & 3.3 & 1.0 \\
$2013-14$ & 4.6 & 2.3 & 2.9 & 2.9 & 2.5 & 2.7 & 1.0 \\
\hline
\end{tabular}

Source: ICTWSS (Version 5.1), Visser (2016). 5 = central or cross-industry level

4 = between central and industry bargaining; $3=$ sector or industry level

$2=$ between sector and company bargaining; $1=$ local or company level.

Table 2: The prominence of the sectoral organization of employment relations in 2014

\begin{tabular}{ccccccc}
\hline Belgium & France & Germany & Italy & Portugal & Spain & U.S. \\
\hline 2 & 1 & 2 & 2 & 1 & 2 & 0
\end{tabular}

Source: ICTWSS (Version 5.1), Visser (2016) / 2 = strong institutions;

$1=$ medium; 0 = weak, or none.

\subsection{Employment protection legislations}

The EPL is the set of norms and procedures that employers have to follow in case of dismissals, including, among others, notification procedures, delays and length relating to notice, severance pay, definition of justified and unfair dismissal, length of trial period, compensation or possibility of reinstatement in case of unfair dismissal, definition of collective dismissal and additional requirements, regulation of fixed-term contracts, and the regulation of temporary work agency. Figure 2 shows the strictness of employment protection for permanent workers (with open-ended contract). The EPL is stricter in Western European economies than in the U.S. Therefore, it appears important to take into account the interaction between experience-rating and EPL. 


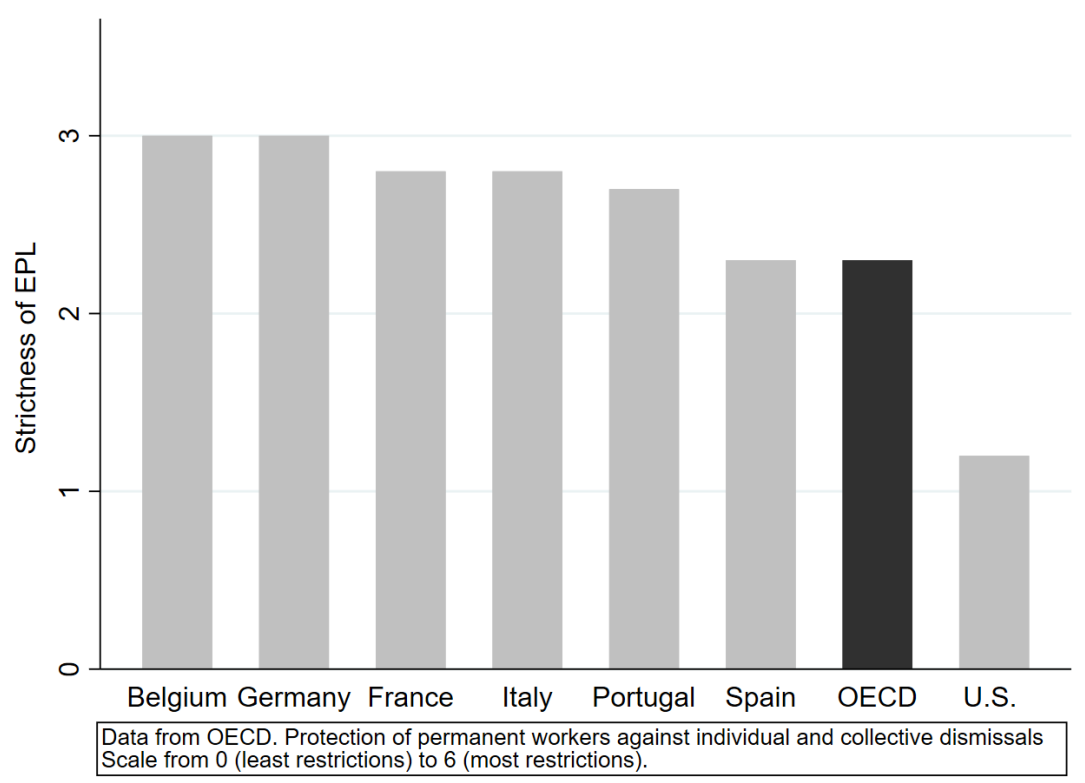

\section{The model}

Our model represents a one-sector Mortensen-Pissarides economy where firms are subject to specific productivity shocks (Mortensen and Pissarides, 1994, 1999). We adapt this framework in order to compare labor market outcomes under firm-level and sector-level bargaining, as Jimeno and Thomas (2013) do. We introduce an employment protection system combining a traditional EPL and layoff taxes that finance the UI (experience-rating ) as in Cahuc and Malherbet (2004) and L'Haridon and Malherbet (2009), in order to assess the effects of ER implementation on labor market outcomes in each bargaining regime.

\subsection{Main assumptions}

Time is continuous with infinite horizon. The economy is composed of a single sector which represents a complete labor market with a unit mass of risk-neutral workers and a mass of risk-neutral firms ${ }^{10}$. They discount the future at an exogenous rate $r>0$. Each firm offers one job. This job may be vacant, in which case the firm incurs a cost $\kappa>0$ which corresponds to the search cost of a worker in a market with frictions. The job may also be occupied by a worker, in which case it produces goods at a level of productivity $\epsilon$ which differs across firms. The level of productivity belongs to a stationary distribution $G$ whose productivity values are included in the interval $[\underline{\epsilon}, \bar{\epsilon}]$. A new job starts at the top of the productivity level $\epsilon=\bar{\epsilon}$. A productive job can be randomly hit, according to a Poisson process, by a specific productivity shock at the exogenous rate $\delta>0$. The shock implies a new productivity value $\epsilon$ from the $G$ distribution. If the new productivity value is less than an endogenous threshold productivity level $\epsilon_{d}$ for which the job remains profitable, the job is destroyed and the worker becomes unemployed. The job is maintained otherwise.

Frictions in the labor market induce the coexistence of unemployed workers and job vacancies. The number of matches is captured by a standard matching technology $m=m(u, v)$, where $u$ is the number of unemployed workers and $v$ is the number of job vacancies. We assume that the function $m$ is continuous, non-negative,

\footnotetext{
${ }^{10}$ As we are not interested in the insurance aspects of ER, risk neutrality for workers and firms is a reasonable assumption. Moreover, it is widely accepted in the literature on matching models (see. Pissarides (2000), Rogerson et al. (2005)).
} 
increasing in $u$ and $v$, homogeneous of degree 1 and checks $m(0, v)=m(u, 0)=0$. Only the unemployed are looking for a job; there is no on-the-job search. Search intensity is constant and exogenous. The constant returns assumption allows to derive

the matching probability for job vacancies: $\frac{m(u, v)}{v}=m\left(\frac{1}{\theta}, 1\right) \equiv q(\theta) \quad$ with $\quad q^{\prime}(\theta) \leq 0$

the matching probability for unemployed workers: $\frac{m(u, v)}{u}=m(1, \theta) \equiv \theta q(\theta) \quad$ with $\quad(\theta q(\theta))^{\prime} \geq 0$

With $\theta=\frac{v}{u}$ denoting labor market tightness. A higher labor market tightness implies either more vacancies for a given number of unemployed persons or fewer unemployed persons for a given number of vacancies. In both situations, the chances for an unemployed person to find a vacancy is greater; thus, the duration of unemployment is shorter.

Firms operate in an institutionalized labor market, including the existence of UI, EPL and collective wage bargaining. The UI/EPL scheme is modeled through the following costs/taxes:

Payroll $\operatorname{tax} \tau$ paid by the firm as long as a worker occupies the job to finance UI.

Layoff tax $\phi$ paid by the firm for each layoff to finance UI and function of the expected duration of the unemployment period. It corresponds to a form of experience-rating.

Set of costs implied in layoffs $c$ paid by the firm for each layoff, representing the administrative and judicial costs incurred by dismissal. It is considered as a payment to a third party, external to the worker-employer relationship. It is not a monetary transfer from employer to worker, since as pointed out by Lazear (1990) and Burda (1992), this kind of transfer does not impact the relevant decision variables of the model.

The layoff $\operatorname{tax} \phi$ and the set of costs $c$ are considered as EPL components since firms take them into account in their dismissal decision-making process following an idiosyncratic shock.

Furthermore, two alternative and exclusive wage-setting regimes are modelled:

Firm-level bargaining regime: fully decentralized within the firm and uncoordinated wage bargaining between an employer and a worker.

Sector-level bargaining regime: sectoral wage bargaining between a trade union and employers' federation that set a wage agreement covering all workers in the sector.

We denote by $b=\{f, s\}$ the bargaining level: $f$ represents the firm-level and $s$ represents the sector-level.

\subsection{Value functions}

The present-discounted value of a job's expected profit for the firm depends on its state. Let $J_{v}^{b}$ be the value of a vacant job. A starting job (before any specific productivity shock) has a value $J_{o}^{b}(\bar{\epsilon})$. A continuing job (that survived a productivity shock) has a value $J_{e}^{b}(\epsilon)$.

The value of a vacant job satisfies

$$
r J_{v}^{b}=-\kappa+q\left(\theta^{b}\right)\left[J_{o}^{b}(\bar{\epsilon})-J_{v}^{b}\right]
$$

At each moment in time, a vacant job implies a search cost $\kappa>0$ for the firm. A vacant job matches an unemployed worker with the probability $q\left(\theta^{b}\right)$. In the event of a match, the firm would gain the difference between the value of a starting job and the value of a vacant job $J_{o}^{b}(\bar{\epsilon})-J_{v}^{b}$. 
The value of a starting job satisfies

$$
r J_{o}^{b}(\bar{\epsilon})=\bar{\epsilon}-(1+\tau) w_{o}^{b}(\bar{\epsilon})+\delta \int_{\epsilon_{d}^{b}}^{\bar{\epsilon}} J_{e}^{b}(x) \mathrm{d} G(x)+\delta G\left(\epsilon_{d}^{b}\right)\left[J_{v}^{b}-c-\phi\right]-\delta J_{o}^{b}(\bar{\epsilon})
$$

Each starting job provides to the employer a value equals to the sum of the instantaneous profit $\bar{\epsilon}-(1+\tau) w_{o}^{b}(\bar{\epsilon})$ and the average gain related to a change in the job's state $\delta \int_{\epsilon_{d}^{b}}^{\bar{\epsilon}} J_{e}^{b}(x) \mathrm{d} G(x)+\delta G\left(\epsilon_{d}^{b}\right)\left[J_{v}^{b}-c-\phi\right]-\delta J_{o}^{b}(\bar{\epsilon})$. We denote $w_{o}^{b}(\bar{\epsilon})$ the wage bargained for the new match. This wage is subject to a payroll tax $\tau$. Following a productivity shock, if the new value of productivity $\epsilon$ is higher than the threshold productivity $\epsilon_{d}^{b}$, the job remains profitable at the value $J_{e}^{b}(\epsilon)$. On the contrary, if the new productivity value is lower than the productivity threshold, the job becomes vacant and the firm has to pay the sum of the costs implied by a layoff $c+\phi$ and thus gets an expected value $J_{v}^{b}-c-\phi$.

The value of a continuing job satisfies

$$
\begin{aligned}
& r J_{e}^{f}(\epsilon)=\epsilon-(1+\tau) w_{e}^{f}(\epsilon)+\delta \int_{\epsilon_{d}^{f}}^{\bar{\epsilon}} J_{e}^{f}(x) \mathrm{d} G(x)+\delta G\left(\epsilon_{d}^{f}\right)\left[J_{v}^{f}-c-\phi\right]-\delta J_{e}^{f}(\epsilon) \\
& r J_{e}^{s}(\epsilon)=\epsilon-(1+\tau) w_{e}^{s}+\delta \int_{\epsilon_{d}^{s}}^{\bar{\epsilon}} J_{e}^{s}(x) \mathrm{d} G(x)+\delta G\left(\epsilon_{d}^{s}\right)\left[J_{v}^{s}-c-\phi\right]-\delta J_{e}^{s}(\epsilon)
\end{aligned}
$$

Each continuing job has survived a productivity shock and produces a flow of output $\epsilon$ (the new productivity level). The firm has to pay the negotiated continuing wage $w_{e}^{b}$, which depends on the new specific productivity in the firm-level bargaining regime and does not in the sector-level one. The continuing job continues to be subject to a potential productivity shock, which would imply the payment of layoff costs in case of job destruction.

The present discounted value of the expected income stream for workers depends on its position. Let $W_{u}^{b}$ be the value if she or he is unemployed, $W_{o}^{b}$ be the value if she or he just started a job and $W_{e}^{b}$ be the value if she or he works in a continuing job.

The expected income stream of an unemployed worker satisfies

$$
r W_{u}^{b}=z+\theta^{b} q\left(\theta^{b}\right)\left[W_{o}^{b}(\bar{\epsilon})-W_{u}^{b}\right]
$$

The unemployed worker is actively seeking a job. At each moment in time she or he receives a net gain $z$ which corresponds to the unemployment benefit and expects to move into employment with probability $\theta^{b} q\left(\theta^{b}\right)$. In the event of a match, the unemployed worker would get a gain corresponding to the difference between the value of being a new worker and the value of being unemployed $W_{o}^{b}(\bar{\epsilon})-W_{u}^{b}$.

The expected income stream of a worker in a starting job satisfies

$$
\begin{aligned}
& r W_{o}^{f}(\bar{\epsilon})=w_{o}^{f}(\bar{\epsilon})+\delta \int_{\epsilon_{d}^{f}}^{\bar{\epsilon}} W_{e}^{f}(x) \mathrm{d} G(x)+\delta G\left(\epsilon_{d}^{f}\right) W_{u}^{f}-\delta W_{o}^{f}(\bar{\epsilon}) \\
& r W_{o}^{s}(\bar{\epsilon})=w_{o}^{s}(\bar{\epsilon})+\delta\left(1-G\left(\epsilon_{d}^{s}\right)\right) W_{e}^{s}+\delta G\left(\epsilon_{d}^{s}\right) W_{u}^{s}-\delta W_{o}^{s}(\bar{\epsilon})
\end{aligned}
$$

A newly hired worker earns a wage that depends on the productivity level of a new match $w_{o}^{b}(\bar{\epsilon})$. He or she faces the risk of undergoing a change in the job's state: resisting the productivity shock and staying productive at a new level of productivity higher than the productivity threshold, or seeing his job destroyed and becoming unemployed. 
The expected income stream for a worker in a continuing job satisfies

$$
\begin{aligned}
& r W_{e}^{f}(\epsilon)=w_{e}^{f}(\epsilon)+\delta \int_{\epsilon_{d}^{f}}^{\bar{\epsilon}} W_{e}^{f}(x) \mathrm{d} G(x)+\delta G\left(\epsilon_{d}^{f}\right) W_{u}^{f}-\delta W_{e}^{f}(\epsilon) \\
& r W_{e}^{s}=w_{e}^{s}+\delta G\left(\epsilon_{d}^{s}\right)\left[W_{u}^{s}-W_{e}^{s}\right]
\end{aligned}
$$

A worker whose job survived a productivity shock earns a wage $w_{e}^{b}$. In the firm-level bargaining regime, this wage has been negotiated with consideration to the new level of productivity following the idiosyncratic shock $w_{e}^{f}(\epsilon)$. In sector-level bargaining, this wage does not depend the new level of productivity $w_{e}^{s}$. In both regimes, the worker still faces a change in the job's state.

\subsection{Wage bargaining}

Wage setting takes place either in a firm-level bargaining regime or in a sector-level bargaining regime. In the firm-level bargaining regime, wage setting is done within the company, in a negotiation between a single employer and a single worker. In the sector-level bargaining regime, wage setting results from a negotiation between a sector-wide employer federation and a sector-wide trade union.

The EPL, involving turnover costs, requires a two-tier wage bargaining: a starting wage and a continuing wage. The starting wage is negotiated at the hiring time by the outsiders. They are not yet protected by the EPL. The continuing wage concerns workers who have already signed a contract, the insiders. They can use the EPL in order to strengthen their position in wage bargaining ${ }^{11}$.

\section{Starting wage}

Starting wage setting has the same features in the two bargaining regimes. It splits the surplus of a new match between the firm and the worker according to a standard Nash bargaining. Indeed, it results from an individualized recruitment process between the unemployed worker and the employer, without any trade union intervention. Under the standard assumption of Nash bargaining, the worker's fallback position is unemployment. This leads to starting wages being pro-cyclical with the labor market tightness $\theta$. The assumption of procyclical starting wages is based on empirical studies (see Pissarides (2009) for a detailed survey ${ }^{12}$ ).

\section{Continuing wage}

Continuing wage setting has different features depending on the bargaining regimes. In the firm-level bargaining regime, the wages are renegotiated each time a specific productivity shock occurs, taking into account the new productivity level. In the sector-level bargaining regime, the negotiations result in a common wage agreement depending on the sector-wide average productivity level, and covering all the workers. Thus, continuing wages do not adjust to firm-specific productivity when a shock occurs. This sector-level bargaining framework can be interpreted as a situation in which sector-level agreements set standards for workers that firm-level agreements cannot lower. Moreover, the sectoral union takes the number of jobs that will be covered by the wage agreement as a given and does not internalize the effect of wage on employment. We argue that many Western countries extend collective bargaining agreements to the entire sector Visser (2013) and that it is a daunting task for the trade union to internalize the effects of wages on employment, knowing the heterogeneity across firms in the sector and the impossibility to reach an agreement appropriate for all of them (Martins, 2014). In short, the mechanism is as follows: firms take into account the sector-level wage agreement to set the productivity threshold under which the jobs are destroyed, and in the process determine the level of employment.

\footnotetext{
${ }^{11}$ See Mortensen and Pissarides (1999)

${ }^{12} \mathrm{C}$. Pissarides shows by citing empirical studies than starting wages are more pro-cyclical than continuing wages.
} 


\subsubsection{Rules of decision}

\section{Job creation decision}

The number of jobs is determined by firms depending on the expected profit from a new vacancy. Following the free-entry assumption, the firm creates a vacancy as soon as the value of a vacancy is positive. At the equilibrium, neither firm must enter into the market and create a vacancy. Thus, as free entry requires that all rents from new vacancy creation are equal to zero, the job creation condition is

$$
J_{v}^{b}=0
$$

By integrating this condition in the value of a vacant job (Eq. 1), it follows that

$$
J_{o}^{b}=\frac{\kappa}{q\left(\theta^{b}\right)}
$$

The average cost of a vacant job must be equal to the expected profit of a new match in equilibrium.

\section{Job destruction decision}

The firm decides to terminate the job when its expected value becomes lower than the payment of the termination costs $c+\phi$. Under the productivity threshold $\epsilon_{d}$, the firm has an interest in laying off the worker and paying the termination costs. Besides, since the value of a job depends positively on the level of productivity $\epsilon$, there is a single level of productivity below which the job becomes unprofitable. Thus, the job destruction condition implies

$$
J_{e}^{b}\left(\epsilon_{d}^{b}\right)=-(c+\phi)
$$

\subsubsection{Starting wage}

Firms and workers seek to pair because they can get an economic surplus. Indeed, a new match makes the job productive and allows the firm to save on vacancy costs. Likewise, the worker leaves unemployment and starts earning a wage that is higher than the unemployment benefit. The starting wage derives from the sharing of the new match surplus

$$
S_{o}^{b}(\bar{\epsilon})=J_{o}^{b}(\bar{\epsilon})-J_{v}^{b}+W_{o}^{b}(\bar{\epsilon})-W_{u}^{b}
$$

Following a Nash bargaining protocol, the surplus is shared between the firm and the worker given a symmetric bargaining power ${ }^{13}$. The starting wage agreement maximizes the product of worker and firm starting surplus, such as

$w_{o}^{b}(\bar{\epsilon})=\operatorname{argmax}\left[W_{o}^{b}(\bar{\epsilon})-W_{u}^{b}\right]\left[J_{o}^{b}(\bar{\epsilon})-J_{v}^{b}\right]$

This results in the following Nash sharing rules ${ }^{14}$

$$
W_{o}^{b}(\bar{\epsilon})-W_{u}^{b}=\frac{1}{2+\tau} S_{o}^{b}(\bar{\epsilon})
$$

\footnotetext{
${ }^{13}$ As in Pissarides (2000).

${ }^{14}$ Detailed calculations are available upon request.
} 


$$
J_{o}^{b}(\bar{\epsilon})-J_{v}^{b}=\frac{1+\tau}{2+\tau} S_{o}^{b}(\bar{\epsilon})
$$

It should be noted that the surplus is not shared equally (fifty-fifty) while the bargaining power is identical. It is shared in the employer's favor $\frac{1}{2+\tau} \leq \frac{1+\tau}{2+\tau}$ because the worker bears the payroll through a smaller share of the surplus.

After some manipulations ${ }^{15}$, we obtain the starting wage equation that holds in equilibrium

$$
w_{o}^{b}(\bar{\epsilon})=\frac{1}{2}\left[\frac{1}{1+\tau}\left(\bar{\epsilon}-\delta(c+\phi)+\theta^{b} \kappa\right)+z\right]
$$

The starting wage decreases with the turnover costs $c$ and $\phi$ and is weighted by productivity shock frequency, and thus corresponds to an outsider wage. Two reasons explain this negative relationship. First, the employer anticipates the payment of these turnover costs in case of a future layoff and negotiates a lower wage in return. Second, during the starting wage bargaining process, the worker does not yet benefit from the EPL to reinforce her or his position in the negotiation. More traditionally, the starting wage depends positively on the unemployment benefit $z$ and the labor market tightness $\theta^{b}$, which both improve the fallback position of the worker in the negotiation and help her or him to get a higher wage. Finally, the starting wage decreases with the payroll tax rate $\tau$ meaning that the worker supports part of it.

\subsubsection{Continuing wage}

\section{Firm-level bargaining regime}

Continuing wage negotiation takes place while the job exists. The worker is protected by the separation costs $(c+\phi)$. In other words, the employer has to pay these costs if the negotiation fails. This implies the surplus of a continuing job as

$$
S_{e}^{f}(\epsilon)=J_{e}^{f}(\epsilon)-J_{v}^{f}+c+\phi+W_{e}^{f}(\epsilon)-W_{u}^{f}
$$

The continuing wage agreement shares this surplus by solving the following Nash maximization problem

$$
w_{e}^{f}(\epsilon)=\operatorname{argmax}\left[W_{e}^{f}(\epsilon)-W_{u}^{f}\right]\left[J_{e}^{f}(\epsilon)-J_{v}^{f}+c+\phi\right]
$$

This leads to the following Nash sharing rules ${ }^{16}$

$$
\begin{aligned}
& W_{e}^{f}(\epsilon)-W_{u}^{f}=\frac{1}{2+\tau} S_{e}^{f}(\epsilon) \\
& J_{e}^{f}(\epsilon)-J_{v}^{f}+c+\phi=\frac{1+\tau}{2+\tau} S_{e}^{f}(\epsilon)
\end{aligned}
$$

After some manipulations, ${ }^{17}$ we obtain the continuing wage equation that holds in equilibrium

$$
w_{e}^{f}(\epsilon)=\frac{1}{2}\left[\frac{1}{1+\tau}\left(\epsilon+r(c+\phi)+\theta^{f} \kappa\right)+z\right]
$$

\footnotetext{
${ }^{15}$ Detailed calculations are available upon request.

${ }^{16}$ Detailed calculations are available upon request.

${ }^{17}$ Detailed calculations are available upon request.
} 
The continuing wage depends on the new firm-specific productivity $\epsilon$ that holds after the shock. Moreover, it departs from the starting wage by its positive relationship with the separation costs $c$ and $\phi$ : insiders take advantage of employment protection to negotiate higher wages, which outsiders can not do.

\section{Sector-level bargaining regime}

The sector-wide employer federation and the sector wide union aim to maximize the aggregate surplus of $n^{s}$ firm-worker pairs, which represents the number of employment relationships covered by the wage agreement. The negotiators set a wage agreement applied to the $n^{s}$ firm-worker pairs, that is a common wage independent of the specific productivity of each firm, such as $w_{e}^{s}(\epsilon)=w_{e}^{s}$.

The aggregate surpluses for workers and firms covered by the wage agreement are respectively

$$
n^{s}\left(W_{e}^{s}-W_{u}^{s}\right)
$$

$$
n^{s} \frac{1}{1-G\left(\epsilon_{d}^{s}\right)} \int_{\epsilon_{d}^{s}}^{\bar{\epsilon}}\left[J_{e}^{s}(\epsilon)-J_{v}^{s}+c+\phi\right] \mathrm{d} G(\epsilon)
$$

For the sake of comparability with the firm-level bargaining regime, we assume that $\epsilon_{d}^{s}$ and $n^{s}$ are given for negotiators. The continuing wage solves the following Nash problem

$$
w_{e}^{s}=\operatorname{argmax}\left[W_{e}^{s}-W_{u}^{s}\right]\left[\frac{1}{1-G\left(\epsilon_{d}^{s}\right)} \int_{\epsilon_{d}^{s}}^{\bar{\epsilon}}\left[J_{e}^{s}(\epsilon)-J_{v}^{s}+c+\phi\right] \mathrm{d} G(\epsilon)\right]
$$

After some manipulations, ${ }^{18}$ we obtain the continuing wage that holds in equilibrium

$$
w_{e}^{s}=\frac{1}{2}\left[\frac{1}{1+\tau}\left[E\left(\epsilon \mid \epsilon \geq \epsilon_{d}^{s}\right)+r(c+\phi)+\theta^{s} \kappa\right]+z\right]
$$

with $E\left(\epsilon \mid \epsilon \geq \epsilon_{d}^{s}\right) \equiv \frac{1}{1-G\left(\epsilon_{d}^{s}\right)} \int_{\epsilon_{d}^{s}}^{\bar{\epsilon}} \epsilon \mathrm{d} G(\epsilon)$ the average productivity across surviving jobs.

The sector-level continuing wage agreement depends positively on the average productivity of firms in the sector. In other words, each employer that has to comply with this agreement cannot adjust the continuing wage according to the job's productivity.

\subsection{Job creation and job destruction}

For each bargaining regime, we derive two new expressions: a job creation condition and a job destruction condition. These conditions will give a solution for $\epsilon_{d}^{b}$ and $\theta^{b}$, which are used in the wage equations and the Beveridge curve equation in order to solve for wages and unemployment.

\subsubsection{Job creation condition}

As the job creation characteristics (free-entry condition, surplus of a new match, starting wage) are the same in both bargaining regimes, job creation conditions have the same structure in the two bargaining regimes.

Using the new match surplus equation (Eq. 13), the starting wage equation (Eq. 17), the free-entry condition (Eq. 10) and after some mathematical manipulations, ${ }^{19}$ we obtain the job creation condition, which defines labor

\footnotetext{
${ }^{18}$ Detailed calculations are available upon request.

${ }^{19}$ Detailed calculations are available upon request.
} 
market tightness, such as

$$
(r+\delta) \frac{\kappa}{q\left(\theta^{b}\right)}=\frac{1}{2}\left[\bar{\epsilon}-\delta(c+\phi)-(1+\tau) z-\theta^{b} \kappa\right]+\frac{1+\tau}{2+\tau} \delta E\left(S_{e}^{b}\right)
$$

with $E\left(S_{e}^{b}\right)=\int_{\epsilon_{d}^{b}}^{\bar{\epsilon}} S_{e}^{b}(x) \mathrm{d} G(x)$ the expected value of the surplus.

The job creation condition ${ }^{20}$ implies that the average cost of a vacant job (LHS) and the expected profit of a newly created job (RHS) must be equal. The average cost of a vacant job increases with labor market tightness: higher tightness leads to a decrease in the probability of finding an unemployed worker for a job vacancy and therefore increases the length of vacancy and mechanically its average cost. The expected profit from a newly occupied job decreases with the labor tightness: higher tightness leads to a higher probability for unemployed workers to find a job and therefore improves their position and their reservation wage. The expected profit also decreases with separation costs $c$ and $\phi$. The link with labor market tightness is as follows: ceteris paribus, an increase in the separation costs leads to a lower expected profit for the firms, which reduces the number of vacancies posted by firms and thus leads to a decline in labor market tightness.

\subsubsection{Job destruction condition}

\section{Firm-level bargaining regime}

Using the existing job value (Eq. 2), the rule of job destruction (Eq. 12), the continuing wage equation (Eq. 23) and after some mathematical manipulations, ${ }^{21}$ we obtain the job destruction condition, which defines the destruction productivity threshold. This condition is

$$
\epsilon_{d}^{f}=(1+\tau) z-r(c+\phi)+\theta^{f} \kappa-\frac{\delta}{r+\delta} \int_{\epsilon_{d}^{f}}^{\bar{\epsilon}} x-\epsilon_{d}^{f} \mathrm{~d} G(x)
$$

The productivity threshold becomes higher (i.e. labor hoarding decreases) with three components. The payroll $\operatorname{tax} \tau$, which increases the labor cost, making the job less profitable for the firm. The unemployment benefit $z$, which improves the worker's non-working position and allows her or him to negotiate a higher wage, making the job less profitable for the firm. Labor market tightness $\theta^{f}$ coupled with the vacancy cost $\kappa$, which corresponds to a proxy of the search cost; in other words, the job's opportunity cost for the employer. The productivity threshold becomes lower (i.e. labor hoarding increases) with two components. The separation costs $c$ and $\phi$ that directly disincentivize employers from destroying the job. The expected change in specific productivity $\frac{\delta}{r+\delta} \int_{\epsilon_{d}^{f}}^{\bar{\epsilon}} x-\epsilon_{d}^{f} \mathrm{~d} G(x)$, which encourages employer to keep the job, expecting an improvement in local productivity conditions.

\footnotetext{
${ }^{20}$ The job creation condition allows to find a solution for $\theta$, which is single. Indeed, the left-hand side (LHS) of Eq. 27 is increasing in $\theta$ (because $q(\theta)^{\prime}<0$ ) while the right-hand side (RHS) is decreasing in $\theta$.

${ }^{21}$ Detailed calculations are available upon request.
} 


\section{Sector-level bargaining regime}

With regard to the job destruction condition, calculation steps are similar to the firm-level regime. ${ }^{22}$ However, under sector-level bargaining, the productivity threshold depends (positively) on the average productivity of jobs in the sector. The latter is linked to the productivity threshold because wages renegotiated under the sectorlevel regime adjust less well to specific productivity shocks than those renegotiated under the firm-level regime. This tends to increase the number of job destructions since they become unprofitable at a faster rate. The job destruction condition under sector-level bargaining is

$$
\epsilon_{d}^{s}=\frac{1}{2}\left[E\left(\epsilon \mid \epsilon \geq \epsilon_{d}^{s}\right)+(1+\tau) z-r(c+\phi)+\theta^{s} \kappa\right]-\frac{\delta}{r+\delta} \int_{\epsilon_{d}^{s}}^{\bar{\epsilon}} x-\epsilon_{d}^{s} \mathrm{~d} G(x)
$$

Factor $\frac{1}{2}$ indicates that the productivity threshold of firms in the sector-level is less elastic to variation of separation costs $c$ and $\phi$.

\subsection{Unemployment}

The unemployment rate evolves over time according to the difference between inflows into unemployment $\delta G\left(\epsilon_{d}^{b}\right)\left(1-u^{b}\right)$ and outflows from unemployment $\theta^{b} q\left(\theta^{b}\right) u^{b}$, such that

$$
\dot{u}^{b}=\delta G\left(\epsilon_{d}^{b}\right)\left(1-u^{b}\right)-\theta^{b} q\left(\theta^{b}\right) u^{b}
$$

In steady-state, inflows to unemployment and outflows from unemployment are equal and thus $\dot{u}=0$. Therefore, the unemployment rate can be expressed as

$$
u^{b}=\frac{\delta G\left(\epsilon_{d}^{b}\right)}{\delta G\left(\epsilon_{d}^{b}\right)+\theta^{b} q\left(\theta^{b}\right)}
$$

This last expression can be interpreted as the Beveridge curve which represents a decreasing and convex relationship between $u$ and $v$. The unemployment rate is decreasing with labor market tightness and increasing with the productivity threshold.

\subsection{Unemployment insurance fund}

To close the model and analyze the effects of the implementation of the ER system, we model an UI budget. The UI budget must respect the balance. Unemployment benefits payment $u z$ is financed by the payroll $\operatorname{tax} \tau$ and the ER tax paid by employers on layoffs $\phi$. The ER tax can be used as an instrument of employment policy, in which case the payroll tax adjustment ensures the fiscal balance. In cases when the payroll tax rate is greater than 0 , the financing of UI is partly shared between firms. In the case where the payroll tax rate is equal to zero, the ER system is "perfect", i.e., only the dismissing firms fund unemployment benefits. The budgetary rule is therefore as follows

$$
u^{b} z=\tau^{b} \overline{w_{o}^{b}} n_{o}^{b}+\tau^{b} \overline{w_{e}^{b}} n_{e}^{b}+\delta G\left(\epsilon_{d}^{b}\right)\left(1-u^{b}\right) \phi
$$

$n_{o}^{b}$ corresponds to the share of new workers and $n_{e}^{b}$ represents the share of continuing workers. We deduce that $n_{e}^{b}=\left(1-u^{b}\right)\left(1-G\left(\epsilon_{d}^{b}\right)\right)$ and $n_{o}^{b}=\left(1-u^{b}\right) G\left(\epsilon_{d}^{b}\right) .{ }^{23}$ Besides, $\overline{w_{o}^{b}}$ and $\overline{w_{e}^{b}}$ represent the average values of wages,

\footnotetext{
${ }^{22}$ Detailed calculations are available upon request.

${ }^{23}$ Proof. $n_{o}^{b}=\left(1-u^{b}\right)-n_{e}^{b}=\left(1-u^{b}\right)-\left(1-u^{b}\right)\left(1-G\left(\epsilon_{d}^{b}\right)\right)=\left(1-u^{b}\right)\left(1-1+G\left(\epsilon_{d}^{b}\right)\right)=\left(1-u^{b}\right) G\left(\epsilon_{d}^{b}\right)$
} 
such as $\overline{w_{o}^{b}}=w_{o}^{b}(\bar{\epsilon}), \overline{w_{e}^{f}}=\frac{1}{1-G\left(\epsilon_{d}^{f}\right)} \int_{\epsilon_{d}^{f}}^{\bar{\epsilon}} w_{e}^{f}(x) \mathrm{d} G(x)^{24}$ and $\overline{w_{e}^{s}}=w_{e}^{s}$. This results in the following expression of the payroll tax ${ }^{25}$

$$
\tau^{b}=\frac{u^{b} z-\phi \delta G\left(\epsilon_{d}^{b}\right)\left(1-u^{b}\right)}{\left(1-u^{b}\right)\left[G\left(\epsilon_{d}^{b}\right) \overline{w_{o}^{b}}+\left(1-G\left(\epsilon_{d}^{b}\right)\right) \overline{w_{e}^{b}}\right]}
$$

An unemployed worker implies a financial cost for the UI fund. The ER-system makes it possible to carry, at least partially, this cost by the firm which lay-off. In order to obtain the expression of ER-tax $\phi$, it is necessary to define the expected cost of an unemployed worker for the unemployment insurance fund $H$. This cost is proportional to the length of unemployment, that is, it depends on the job-finding rate, such as

$$
r H^{b}=z+\theta^{b} q\left(\theta^{b}\right)\left[0-H^{b}\right]
$$

This expected cost increases with the level of unemployment benefit $z$ and decreases with the job-finding rate $\theta^{b} q\left(\theta^{b}\right)$.

Since the ER system can be perfect or partial, we define $\rho$ as the ER-index. It stands for the degree of completeness, that means the proportion to which the expected cost of an unemployed worker is financed by the dismissing firm. It results from this that ER tax is equal to $\phi^{b}=\rho H^{b}$. By injecting $H^{b}=\frac{\phi^{b}}{\rho}$ in (Eq. 43), we get the following expression of ER $\operatorname{tax}^{26}$

$$
\phi^{b}=\frac{\rho z}{r+\theta^{b} q\left(\theta^{b}\right)}
$$

ER tax increases with the amount of the unemployment benefit $z$. It is also increases with the degree of completeness of the ER-system $\rho$, since the more perfect the system, the less the funding of UI is pooled, and therefore the more directly the firm is responsible for its financing. Finally, it decreases with job-finding probability and thus with labor market tightness $\theta^{b}$.

\subsection{Equilibrium}

We consider steady-state equilibrium, in which all aggregate variables are stationary over time. They are constant although firms and workers are subject to uncertainty in their individual experiences. We characterize the equilibrium in each bargaining regime. For each level of bargaining, a steady-state equilibrium corresponds to the value of 5 endogenous variables $\left(u, \theta, \epsilon_{d}, \tau, \phi\right)$ and the two wages $\left(w_{o}, w_{e}\right)$ which satisfy job creation and job destruction conditions, two wage equations, the flow equilibrium condition for unemployment, equations of payroll tax and experience-rating tax.

\section{Common in both bargaining regimes}

Labor market tightness (job creation condition)

$$
(r+\delta) \frac{\kappa}{q\left(\theta^{b}\right)}=\frac{1}{2}\left[\bar{\epsilon}-\delta(c+\phi)-(1+\tau) z-\theta^{b} \kappa\right]+\frac{1+\tau}{2+\tau} \delta E\left(S_{e}^{b}\right)
$$

\footnotetext{
${ }^{24}$ This expression comes from calculating the average of a continuous function set over an interval: $m=\frac{1}{b-a} \int_{a}^{b} f(x) \mathrm{d} x$. In our case: $\overline{w_{e}^{f}}=\frac{1}{G(\bar{\epsilon})-G\left(\epsilon_{d}^{f}\right)} \int_{\epsilon_{d}^{f}}^{\bar{\epsilon}} w_{e}^{f}(x) \mathrm{d} G(x)=\frac{1}{1-G\left(\epsilon_{d}^{f}\right)} \int_{\epsilon_{d}^{f}}^{\bar{\epsilon}} w_{e}^{f}(x) \mathrm{d} G(x)$

${ }^{25}$ Detailed calculations are available upon request.

${ }^{26}$ Detailed calculations are available upon request.
} 
Payroll tax

$\tau^{b}=\frac{u^{b} z-\phi^{b} \delta G\left(\epsilon_{d}^{b}\right)\left(1-u^{b}\right)}{\left(1-u^{b}\right)\left[G\left(\epsilon_{d}^{b}\right) \overline{w_{o}^{b}}+\left(1-G\left(\epsilon_{d}^{b}\right)\right) \overline{w_{e}^{b}}\right]}$

Experience-rating tax

$\phi^{b}=\frac{\rho z}{r+\theta^{b} q\left(\theta^{b}\right)}$

Unemployment rate

$u^{b}=\frac{\delta G\left(\epsilon_{d}^{b}\right)}{\delta G\left(\epsilon_{d}^{b}\right)+\theta^{f} q\left(\theta^{b}\right)}$

\section{Firm-level bargaining regime}

Productivity threshold (job destruction condition)

$\epsilon_{d}^{f}=(1+\tau) z-r(c+\phi)+\theta^{f} \kappa-\frac{\delta}{r+\delta} \int_{\epsilon_{d}^{f}}^{\bar{\epsilon}} x-\epsilon_{d}^{f} \mathrm{~d} G(x)$

\section{Sector-level bargaining regime}

Productivity threshold (job destruction condition)

$\epsilon_{d}^{s}=\frac{1}{2}\left[E\left(\epsilon \mid \epsilon \geq \epsilon_{d}^{s}\right)+(1+\tau) z-r(c+\phi)+\theta^{s} \kappa\right]-\frac{\delta}{r+\delta} \int_{\epsilon_{d}^{s}}^{\bar{\epsilon}} x-\epsilon_{d}^{s} \mathrm{~d} G(x)$

\section{Employment protection reform: numerical analysis}

There are multiple and opposite channels of influence on equilibrium outcomes following the implementation of the ER system.

Theoretically, ceteris paribus, implementing an ER tax increases the amount of separation costs for firms. A more stringent EPL leads to labor hoarding and thus a lower job destruction rate, but also reduces the expected profit of jobs for employers and thus their incentives to create jobs. Furthermore, the negotiated wages will react to changes in EPL strictness, with different reactions depending on the bargaining regime. Indeed, as argued by Cahuc (2014), when wages are flexible, they are adjusted when EPL becomes more rigorous, while it is not the case when wages are downward rigid. In addition, the implementation of an ER tax that finances UI implies a payroll subsidy, given a balanced UI budget. This decrease in the payroll tax is taken into account in wage negotiations and involves changes in wage levels, which may differ depending on the bargaining system. Thus, the effect on the labor cost and therefore the employers' incentives to create and destroy jobs are ambiguous; indeed, a lower labor cost increases the job's expected profit and therefore increases the number of job creations, while it makes the job cheaper and therefore more resilient to negative productivity shocks. This complexity and the seemingly ambiguous impact of ER tax on labor market outcomes require quantitative analysis ${ }^{27}$.

To gain a better understanding of the effects of the introduction of an ER tax that finances the UI, we analyze three different reform scenarios.

\footnotetext{
${ }^{27}$ In practice, we use the fsolve function from the Optimization Toolbox in Matlab (Version 9.3.0.713579(R2017b)) designed to solve nonlinear systems. For all numerical exercises, we check that each solution provided by matlab is associated with a value for the 'exitflag' equal to 1
} 
Table 3: Three different reform scenarios

\begin{tabular}{clcl}
\cline { 2 - 4 } & \multicolumn{1}{c}{ Addition } & \multicolumn{1}{c}{ Substitution } & \multicolumn{1}{c}{ EPL only } \\
\cline { 2 - 4 } Idea & $\begin{array}{l}\text { ER tax is juxtaposed } \\
\text { with the existing EPL }\end{array}$ & $\begin{array}{l}\text { ER tax is implemented } \\
\text { by substituting the ex- } \\
\text { isting EPL }\end{array}$ & $\begin{array}{l}\text { A basic layoff tax is } \\
\text { juxtaposed to the exist- } \\
\text { ing EPL }\end{array}$ \\
\hline Model & $\Delta \rho>0 \rightarrow c+\phi$ & $\Delta \phi=-\Delta c \rightarrow \Delta \rho>0$ & \multicolumn{1}{c}{$\Delta c>0$} \\
\hline Interpretation & $\begin{array}{l}\text { Policymakers imple- } \\
\text { ment ER tax to finance } \\
\text { UI without relaxation } \\
\text { of the existing EPL }\end{array}$ & $\begin{array}{l}\text { Policymakers imple- } \\
\text { ment ER tax to finance } \\
\text { UI with a relaxation of } \\
\text { the existing EPL }\end{array}$ & $\begin{array}{l}\text { Policymakers increase } \\
\text { the EPL stringency, } \\
\text { without implementing } \\
\text { ER }\end{array}$ \\
\hline
\end{tabular}

The addition and the substitution scenarios include the introduction of an ER tax that finances UI. However, the addition scenario corresponds to a reform that simply adds the ER tax, which burdens the existing EPL. The substitution scenario corresponds to a reform that adds the ER tax while relaxing the existing EPL in a similar proportion. We model two different scenarios of ER implementation for two reasons. On the one hand, the addition scenario allows us to take into account the joint effects of the payroll subsidy and the increase in separation costs induced by the ER tax, which can have opposite effects on the labor flows and especially on job creation, the scope of which may be different according to the wage bargaining regime. On the other hand, it seems very difficult to reform the existing EPL in many European countries, as it is a well-established institution to which many citizens are attached. It is reasonable to assume that many policy-makers will not reduce the rigor of the existing EPL while implementing ER, at least initially (see recent debates in France on taxing employers over the use of temporary contracts). The third scenario, 'EPL only', does not introduce an ER tax; it consists simply in an increase in the existing EPL's stringency. This third scenario is useful for two reasons. Firstly, it complements the work of Jimeno and Thomas (2013), who do not model labor turnover costs. Secondly, it helps to better understand the effects of ER by avoiding the payroll subsidy effects and thus serving as a benchmark.

Finally, to analyze the effects of each reform on labor market outcomes, in each bargaining regime, we compare the post-reform position with a pre-reform position in which there is no ER tax financing UI. The only two labor market policy instruments in the pre-reform position are the payroll tax that finances UI and the existing costs of layoffs (existing EPL).

\subsection{Calibration and pre-reform position}

Parameters are calibrated based on data from the French labor market, which in terms of labor market institutions - especially the collective bargaining structure and the employment protection legislation -, is fairly representative of Western European countries. As the French economy is characterized by a strong influence of sectoral negotiations (see. section 2), we calibrate the model with the sector-level bargaining regime as a baseline.

We start by setting standard parameters in the literature. The period is set to one quarter with a discount rate $r$ set to 0.01 . The $G$ distribution of specific productivity shocks is assumed to be uniform between $[0,1]$ and the new match productivity $\bar{\epsilon}$ is set to 1 . We use a Cobb-Douglas specification for the matching function, $m(u, v)=A u^{\alpha} v^{1-\alpha}$, which implies a job finding rate ${ }^{28}$ of $\theta q(\theta)=A \theta^{1-\alpha}$. $\alpha$ corresponds to the elasticity of the matching function and set at 0.5 as assumed in most of the literature (Petrongolo and Pissarides, 2001). The matching efficiency parameter $A^{29}$ set to 0.180 , the vacancy cost $\kappa$ set to 0.4116 and the productivity shock frequency $\delta$ set to 0.0154 are calibrated in order to target the following moments of the French economy: an unemployment rate of 9.4\% (OECD), a labor market tightness of 0.562 (average value on Q1-2005/Q1-2017;

\footnotetext{
${ }^{28} \theta q(\theta)=\frac{m(u, v)}{u}=\frac{A u^{\alpha} v^{1-\alpha}}{u}=A\left(\frac{v}{u}\right)^{1-\alpha}=A(\theta)^{1-\alpha}$.

${ }^{29} A=\frac{\theta q(\theta)}{\left(\theta^{*}\right)^{1-\alpha}}$ with $\theta q(\theta)=0.135$ the targeted value of job-finding rate and $\theta^{*}=0.562$ the targeted value of labor market tightness, we obtain: $A=0.180$.
} 
DARES), a job-finding probability estimated at 0.135 (Hairault et al., 2015) and a payroll tax (to finance UI) of 5.0\% (Pôle Emploi, 2018). Finally, the values of the unemployment benefit $z$ and the set of costs implied in layoffs $c$, respectively set to 0.6269 and 1.7739 are chosen to fit the following features of the French UI system and the EPL: unemployment benefits equal to $71 \%$ of the average wage (the average replacement ratio in France, Unedic, 2016) and layoff costs approximately equal to $50 \%$ of the average annual wage (Kramarz and Michaud, 2010). The values are summarized in Table 4.

Table 4: Parameters values (quarterly data) - Baseline: sector-level bargaining regime

\begin{tabular}{|c|c|c|c|c|c|c|}
\hline \multicolumn{2}{|c|}{ Labor Market Parameters Notation } & \multirow[t]{2}{*}{ Value } & \multirow[t]{2}{*}{ Calibration Targets } & \multirow[t]{2}{*}{ Notation } & \multirow[t]{2}{*}{ Value } & \multirow[t]{2}{*}{ Source } \\
\hline Baseline Parameters & & & & & & \\
\hline Matching efficiency & A & 0.180 & Unemployment rate & $u$ & 0.094 & OECD \\
\hline Elasticity of matching function & $\alpha$ & 0.5 & Labor market tightness & $\theta$ & 0.562 & av. Q1-2005/Q1-2017; DARES \\
\hline New match productivity & $\bar{\epsilon}$ & 1 & Payroll tax & $\tau$ & 0.05 & Pole Emploi, 2018 \\
\hline Interest rate & $r$ & 0.01 & Job-finding rate & $\theta q(\theta)$ & 0.135 & Hairault et al. (2015) \\
\hline \multicolumn{7}{|l|}{ Calibrated Parameters } \\
\hline Vacancy cost & $\kappa$ & 0.4116 & & & & \\
\hline Productivity shock frequency & $\delta$ & 0.0154 & & & & \\
\hline Unemployment benefits & $z$ & 0.6269 & & & & \\
\hline \multicolumn{7}{|l|}{ Policy parameters } \\
\hline Firing cost & $c$ & 1.7739 & & & & \\
\hline Experience rating index & $\rho$ & 0 & & & & \\
\hline
\end{tabular}

Table 5: Pre-reform position

\begin{tabular}{llll}
\hline Variable & Notation & Bargaining regime & \\
\cline { 3 - 4 } & & Sector-level (baseline) & Firm-level \\
\hline Unemployment rate (\%) & $u$ & $\mathbf{9 . 7 0 0}$ & $\mathbf{9 . 2 2 0}$ \\
Labor market tightness & $\theta$ & $\mathbf{0 . 5 2 8}$ & $\mathbf{0 . 5 3 5}$ \\
Productivity threshold & $\epsilon_{d}$ & $\mathbf{0 . 9 1 4}$ & $\mathbf{0 . 8 7 0}$ \\
Average starting wage & $\overline{w_{o}}$ & $\mathbf{0 . 8 6 6}$ & $\mathbf{0 . 8 7 0}$ \\
Average continuing wage & $\overline{w_{e}}$ & $\mathbf{0 . 8 6 6}$ & $\mathbf{0 . 8 6 0}$ \\
Labor cost starting job & $\overline{w_{o}}(1+\tau)$ & $\mathbf{0 . 9 3 3}$ & $\mathbf{0 . 9 3 3}$ \\
Labor cost continuing job & $\overline{w_{e}}(1+\tau)$ & $\mathbf{0 . 9 3 4}$ & $\mathbf{0 . 9 2 3}$ \\
Payroll tax & $\tau$ & $\mathbf{0 . 0 7 7}$ & $\mathbf{0 . 0 7 3}$ \\
Budget (\%) & $B / Y$ & $\mathbf{6 . 9 2 0}$ & $\mathbf{6 . 6 0 0}$ \\
Experience-rating tax index & $\rho$ & $\mathbf{0 . 0 0 0}$ & $\mathbf{0 . 0 0 0}$ \\
\hline
\end{tabular}

Table 5 displays the labor market outcomes of the pre-reform situation under each bargaining regime. We are mainly interested in the unemployment rate, which is a major variable for policy-makers. In this context, the labor market performs better under the firm-level bargaining regime than under the sector-level one. This is due to higher labor market tightness and a lower productivity threshold, which means more job creation and less job destruction in the firm-level bargaining economy. These results illustrate that decentralized negotiation at the firm level makes it possible for firms to partially adjust wages to idiosyncratic productivity in the event of a shock. This reduces the loss of job profitability following a shock and therefore its expected profitability for employers. Conversely, the unemployment rate is higher in the sector-level bargaining economy because firms' inability to perform wage adjustments following an idiosyncratic shock, since they are required to pay the collectively negotiated wage common to the entire industry. Indeed, in this framework, the wage is negotiated between social partners and is binding on all firms. Since this sectoral wage does not respond to firm-specific productivity, firms' profits fall faster in case of a shock and the productivity threshold, which defines the lower limit below which a job becomes unprofitable, is reached quickly.

Regarding bargained wages, the starting wages negotiated by outsiders are lower in the sector-level bargaining regime than in the firm-level bargaining one. Indeed, since the labor market is less tight in the sectoral regime, 
competing outsiders accept lower wages. The insiders' wages are higher in the sector-level regime than in the firm-level one. The difference is explained by the gap in productivity threshold between the two regimes. Indeed, under the sectoral regime, insiders can make greater use of separation costs and unemployment benefit to get higher wages: the higher probability of destroying jobs because of the impossibility of lowering wages in the event of a negative shock enforces employers to accept wage claims from insiders.

These results complement the work of Jimeno and Thomas (2013), who pointed out that labor market performance under a firm-level bargaining regime is better than under a sector-level bargaining regime. Nevertheless, they do not model EPL which is, however, predominant in European labor markets. Our results show that taking EPL into account does not change their main result.

Finally, by relating the unemployment cost $B=u z$ to the economy's aggregate output (net of search costs) $Y^{b}=\left(n_{o}^{b}+n_{e}^{b}\right)\left[\bar{\epsilon}+\int_{\epsilon_{d}^{b}}^{\bar{\epsilon}}(x-\bar{\epsilon}) \mathrm{d} G(x)\right]-u^{b} k \theta^{b}$, we obtain the UI budget size. We observe that financing UI requires more resources under the sector-level bargaining regime than under the firm-level one. Taking differences in wage levels into account, it implies a higher payroll tax under the sector-level bargaining regime, leading to a higher labor cost. Logically, since there is still no ER in the pre-reform position, the ER tax index is equal to 0 .

\subsection{Experience-rating implementation in addition to the existing EPL}

We consider here a scenario in which policymakers implement an ER-tax to finance UI without relaxing the existing EPL. The ER-tax $\phi$ is implemented by an increase in the ER-index $\rho$ that is used as a policy instrument. In other words, as soon as the ER-index $\rho>0$, the separation costs become $c+\phi$. For the moment, we are content to analyze the effects on the labor market outcomes of a complete ER system implementation, characterized by $\rho=1$, which implies the disappearance of the payroll tax in the financing of UI $(\tau=0)$; the financing of UI is entirely individualized. Indeed, the increase in the ER-index means that the employer must individually support a larger share of the unemployment cost created by its layoff, via a higher ER tax.

Table 6 depicts the absolute changes (in percentage points for the unemployment rate and the budget size) in labor market outcomes after the addition scenario reform. First, we begin by presenting the effects of the addition scenario regardless of the bargaining regime. In a second step, we will compare the effects depending on the bargaining regime.

The addition scenario reduces unemployment. The increase in separation costs reduces the expected profitability of a job and therefore the number of creations. At a given unemployment rate, the decline in the number of job vacancies posted leads to a relatively small decrease in labor market tightness. Indeed, as the increase in separation costs is accompanied by a reduction of the payroll tax, its negative impact on job creation is largely eliminated. In other words, the reduction of the payroll tax increases the expected profitability of jobs and thus offsets the negative effect of higher separation costs on labor market tightness. The only remaining factor is the positive effect of the increase in separation costs on labor hoarding, implying less job destruction, leading to a drop in the unemployment rate. For a better understanding of the effects of the reduction of the payroll tax on incentives to create and destroy jobs, we need to observe wage evolutions. Indeed, we know that wages are renegotiated upwards in the event of a payroll tax cut. If the increase is relatively sharp compared to the variation in payroll tax, then the labor cost could increase, reducing the profitability of jobs and generating more job destruction and less job creation. In our framework, the wage increase remains limited relatively to the payroll tax reduction. Consequently, the labor cost is lower.

The unemployment rate declines in both bargaining regimes, but the decline is much greater in the firmlevel regime. This is due to a different impact on job destruction. Indeed, while the decline in job creation is almost similar in the two bargaining regimes (although slightly higher in the sector-level one), the decline in job destruction is greater in the firm-level regime. This is explained by the possibility of adjusting wages to the new specific productivity following a shock under the firm-level regime, unlike in the sector-level regime. Indeed, following a productivity shock, the employer must make a trade-off between paying the separation costs and letting the less productive worker go or keeping her or him in the job (labor hoarding). The decrease in the worker's productivity induces a decrease in his profitability, but less strongly in the firm-level regime than in the 
sector-level regime. Indeed, in the firm-level plan, the employer has the possibility to renegotiate the worker's wage so that it can partially adjust to the new productivity; this mitigates the drop in the worker's profitability for the firm. Therefore, it leads to a more likely trade-off towards labor retention than in the sector-level regime where the wage does not adjust to the idiosyncratic productivity. Moreover, the evolution of the average continuing wage helps to explain these results. They increase in both bargaining regimes, but more strongly in the sector-level regime, which implies a lower drop in labor costs compared to the firm-level regime. It strengthens the lower increase in labor retention and the higher decrease in job creation. Regarding budget size, the decline is stronger under the firm-level bargaining regime, particularly because of the stronger decline in the unemployment rate.

To sum up, the possibility of internal flexibility (firm-specific adjustments) plays a role in the evolution of labor market outcomes following the implementation of an ER tax according to the addition scenario.

Table 6: Comparative statics - Post-reform position - Addition scenario

\begin{tabular}{|c|c|c|c|c|c|}
\hline \multirow[t]{3}{*}{ Variable } & \multirow[t]{3}{*}{ Notation } & \multicolumn{4}{|c|}{ Bargaining regime } \\
\hline & & \multicolumn{2}{|l|}{ Sector-level } & \multicolumn{2}{|l|}{ Firm-level } \\
\hline & & Pre-reform value & Abs. change & Pre-reform value & Abs. change \\
\hline Unemployment rate (\%) & $u$ & 9.700 & -0.500 & 9.220 & -0.900 \\
\hline Labor market tightness & $\theta$ & 0.528 & -0.027 & 0.535 & -0.029 \\
\hline Productivity threshold & $\epsilon_{d}$ & 0.914 & -0.076 & 0.870 & -0.113 \\
\hline Average starting wage & $\overline{w_{o}}$ & 0.866 & -0.001 & 0.870 & -0.004 \\
\hline Average continuing wage & $\overline{w_{e}}$ & 0.866 & 0.039 & 0.860 & 0.026 \\
\hline Labor cost starting job & $\overline{w_{o}}(1+\tau)$ & 0.933 & -0.064 & 0.933 & -0.062 \\
\hline Labor cost continuing job & $\overline{w_{e}}(1+\tau)$ & 0.934 & -0.025 & 0.923 & -0.033 \\
\hline Budget $(\%)$ & $B / Y$ & 6.900 & -0.351 & 6.600 & -0.586 \\
\hline
\end{tabular}

Note: 'Abs. change' gives the absolute change relative to the pre-reform position (in percentage points for the unemployment rate and the Budget). The layoff tax $\phi$ are respectively 4.563 in the sector-level regime and 4.541 in the firm-level one.

\subsection{Experience-rating implementation as a substitute to the existing EPL}

We consider here a scenario in which policymakers implement an ER-tax to finance UI accompanied by a relaxation of the existing EPL stringency. The ER-tax $\phi$ is implemented as a substitute of the set costs implied in layoffs $c$, such as $\Delta \phi=-\Delta c$, which implies that the ER index becomes positive $(\Delta \rho>0)$. We analyze the effects on the labor market outcomes of a complete substitution of $c$ by $\phi$, which does not involve a complete ER system $\rho<1^{30}$. Thus, the payroll tax continues to partly finance UI $(\tau>0)$; the UI financing remains partly mutualized.

Table 7 shows the absolute changes (in percentage points for the unemployment rate and the budget size) of labor market outcomes after the substitution scenario reform. As in the addition scenario, we will first present the main effects without distinguishing the level of negotiations. In a second step, we will compare the results according to the bargaining regime.

The substitution scenario leads to a decrease in the unemployment rate, due to a significant rise in the job creation rate and a small decrease in the job destruction rate. The mechanism is as follows: this scenario does not increase separation costs but involves a reduction in the payroll tax. These two effects, which make jobs more profitable, lead to strong job creation growth. Moreover, this increase in profitability makes jobs more resistant to idiosyncratic shocks, and thus tends to reduce the job destruction rate (although separation costs remain unchanged). Wages increase for outsiders and insiders in the same proportions: the reduction in the payroll tax benefits all employees and insiders cannot use the increase in separation costs (which does not exist in this scenario) to their advantage. Finally, labor costs fall only slightly due to opposite variations in payroll tax and wage. This scenario leads to a reduction in the UI's financial burden.

Then, if we compare the two bargaining regimes, we see that unemployment drops in both of them, but the decline is slightly higher in the sector-level regime. The other variables display relatively similar variations between the two bargaining regimes. Indeed, since separation costs do not vary, whether or not wages can be adjusted to productivity following a shock is irrelevant. Only the change in the payroll tax plays a role here. The

\footnotetext{
${ }^{30}$ In this scenario, the ER-tax $\phi$ is used as an instrument, implying that the ER-index $\rho$ is endogenous. In the post-reform situation, the values are as follows: $c=0, \phi=1.7739$ and $\rho=0.41$.
} 
slight difference in the evolution of the unemployment rate in favor of the sector-level regime is explained by the higher increase in job creation due to a greater fall in labor costs. Indeed, in the pre-reform position, the job destruction rate is higher in the sectoral bargaining regime than in the firm-level bargaining regime. Thus, with a balanced unemployment insurance budget, the introduction of the ER tax allows for a more significant reduction in the payroll tax in the sectoral system.

In summary, in the substitution scenario, the bargaining regime appears to play a less decisive role in determining the extent of the effects of ER implementation.

Table 7: Comparative statics - Post-reform position - Substitution scenario

\begin{tabular}{|c|c|c|c|c|c|}
\hline \multirow[t]{3}{*}{ Variable } & \multirow[t]{3}{*}{ Notation } & \multicolumn{4}{|c|}{ Bargaining regime } \\
\hline & & \multicolumn{2}{|l|}{ Sector-level } & \multicolumn{2}{|l|}{ Firm-level } \\
\hline & & Pre-reform value & Abs. change & Pre-reform value & Abs. change \\
\hline Unemployment rate (\%) & $u$ & 9.700 & -0.354 & 9.220 & -0.332 \\
\hline Labor market tightness & $\theta$ & 0.528 & 0.043 & 0.535 & 0.041 \\
\hline Productivity threshold & $\epsilon_{d}$ & 0.914 & -0.002 & 0.870 & -0.003 \\
\hline Average starting wage & $\frac{w}{w_{o}}$ & 0.866 & 0.026 & 0.870 & 0.025 \\
\hline Average continuing wage & $\overline{w_{e}}$ & 0.866 & 0.026 & 0.860 & 0.024 \\
\hline Labor cost starting job & $\overline{w_{o}}(1+\tau)$ & 0.933 & -0.002 & 0.933 & -0.001 \\
\hline Labor cost continuing job & $\overline{w_{e}}(1+\tau)$ & 0.934 & -0.002 & 0.923 & -0.002 \\
\hline Budget (\%) & $B / Y$ & 6.900 & -0.271 & 6.600 & -0.252 \\
\hline
\end{tabular}

Note: 'Abs. change' gives the absolute change relative to the pre-reform position (in percentage points for the unemployment rate and the Budget). The ER indexes $\rho$ are respectively 0.413 in the sector-level regime and 0.415 in the firm-level one.

\subsection{Which reform scenario to recommend?}

We successively assessed the effects of ER tax implementation via the addition scenario and via the substitution scenario. It appears that both scenarios, even if their effects on labor outcomes are not all similar (in particular regarding labor market tightness and the starting wage), may be recommended if the main objective is to reduce the unemployment rate. It is now necessary to establish which scenario should be recommended under a given collective bargaining regime.

The addition scenario we tested involves a complete ER system $(\rho=1)$ while the substitution scenario leads to a partial ER system $(\rho=0.41)$. In order to compare the effects of the two reform scenarios on labor market outcomes, we have to compare them at similar levels of individualization in the financing of UI, i.e. with a similar ER index. Therefore, we simulate the addition scenario up to an ER-index $\rho$ of 0.41 , which corresponds to the maximum ER-index reached in the substitution scenario (full substitution). The evolution of labor market outcomes following these two scenarios is compared with the evolution of labor market outcomes following the 'EPL only' scenario, where the rise in separation costs $c$ is equivalent to the increase in the ER-tax $\phi$ of the addition scenario for the sake of comparability. ${ }^{31}$ It is relevant to consider the 'EPL only' scenario as a benchmark because this makes it possible to isolate the increase in separation costs and interactions with the negotiation regime. Furthermore, investigating the effects of a partial ER system (an ER index below 1) on labor market outcomes is a credible exercise. Indeed, the existing ER-system in the U.S. maintain a share of pooling in the financing of UI of around $40 \%$ (Cahuc et al., 2014). Moreover, in the U.S., unemployment benefits are lower and paid over a shorter period of time, making easier for companies to bear the costs of workforce management compared to Western European countries where unemployment benefits are higher and unemployment periods are longer (Margolis and Fougère, 2000).

Figure 3 illustrates the evolution of labor market outcomes according to the ER index in each reform scenario. Since the addition scenario and the 'EPL only' scenario both imply a similar increase in separation costs, it is relevant to start by comparing their effects, and then to compare them with the effects of the substitution scenario.

The effects on unemployment are clearly distinct. Under the firm-level bargaining regime, the rise of separation costs only (EPL only) does not cause variations in the unemployment rate, while the ER tax addition lowers

\footnotetext{
${ }^{31}$ For example: if following the addition scenario, a given ER-index $\rho$ yields an ER-tax $\phi$ equal to X, we increase $c$ by X in the 'EPL only' scenario, $\rho$ and $\phi$ remaining equal to 0 .
} 
it. Under the sector-level bargaining regime, the difference in evolution is even greater: the rise of separation costs only increases the unemployment rate, while the ER tax addition reduces it. Finally, the substitution scenario has an essentially similar effect on the unemployment rate to the addition scenario under the firm-level bargaining regime, whereas it results in a more significant decline under the sector-level bargaining regime. These results suggest the following first recommendations: if the main objective is unemployment reduction, the addition scenario should be recommended under a firm-level bargaining regime and the substitution scenario should be recommended under a sector-level regime, whereas a simple increase in EPL stringency has either no effect or a negative one.

As the unemployment rate depends on job creation and job destruction flows, their evolution must be observed to understand changes in unemployment following a reform scenario. Regarding job destruction, under both bargaining regimes, there is a positive effect of the addition and the 'EPL only' scenarios on labor hoarding through a lowering of the productivity threshold, while the substitution scenario has no impact. However, comparatively to the substitution scenario, the introduction of an ER tax by addition has a greater impact on labor hoarding under the firm-level bargaining regime than under the sector-level one. The additional ER tax therefore allows for a greater reduction in job destruction under a firm-level bargaining regime than a sector-level one. Regarding job creation, under both bargaining regimes, the effects of the three scenarios are very different. The 'EPL only' scenario has a strongly negative effect on labor market tightness under the firm-level bargaining regime, and even more so under the sector-level one. In the addition scenario, this effect is less strong, but still negative. On the contrary, the substitution scenario has a clearly positive effect on labor market tightness.

Following this analysis of labor market flows, we understand why the substitution scenario performs better than the addition scenario in reducing the unemployment rate under the sector-level bargaining regime - due to the less significant lowering of the productivity threshold. Indeed, the addition (substitution) scenario has similar adverse (positive) effects on labor market tightness under both bargaining regimes. However, both scenarios have a lower effect on the productivity threshold under the sector-level bargaining regime.

Regarding the evolution of negotiated wages, we observe that under both bargaining regimes, an increase in separation costs only leads to lower starting and continuing wages, while the addition scenario has no effect on starting wages and a positive effect on continuing wages. The substitution scenario has the bigger positive effect on both starting and continuing wages. To fully analyze the effects of wage developments on job destruction and job creation, it is also relevant to look at the cost of labor paid by the employer $w(1+\tau)$. Indeed, following the introduction of the ER tax in the financing of UI, the payroll tax decreases, but in different proportions depending on how wages have evolved. We observe that the labor cost of starting jobs decreases strongly under the addition scenario and the 'EPL only' scenario under both bargaining regimes and remains stable following the substitution scenario. Regarding the labor cost of continuing jobs, again, the addition and the 'EPL only' scenarios result in the most significant decreases, but this time more strongly under the firm-level bargaining regime. 
Figure 3: Evolution of labor market outcomes according to the ER-index

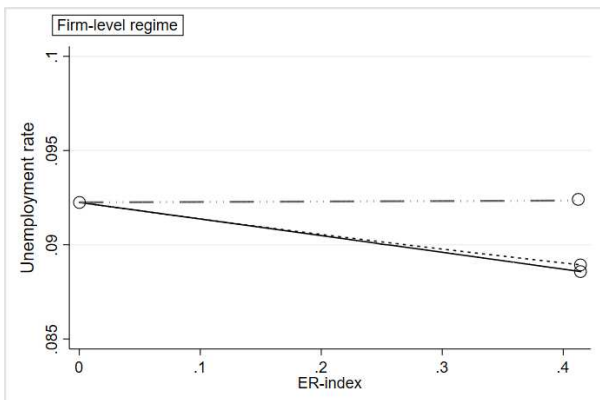

Sector-level regime
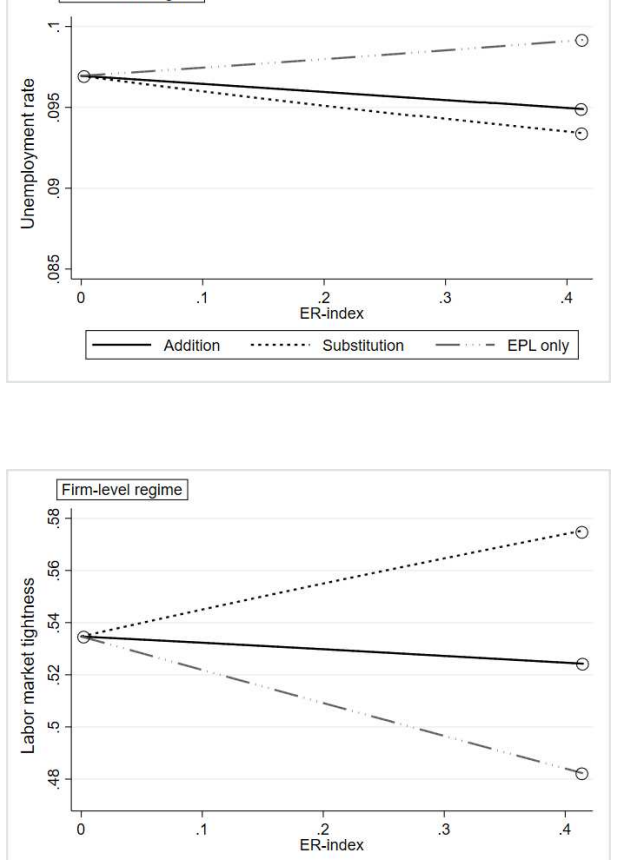

Sector-level regime

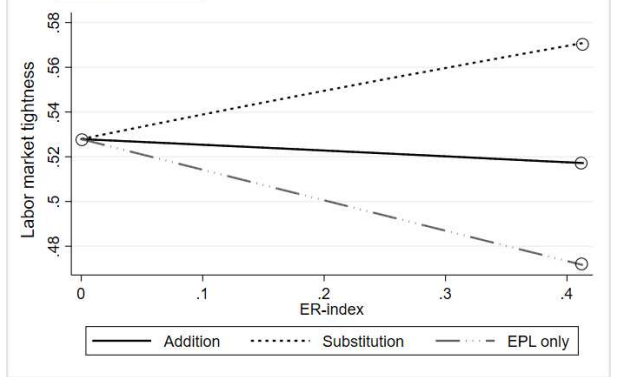

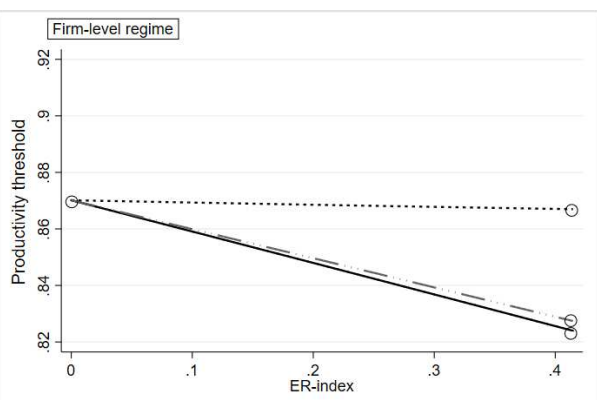
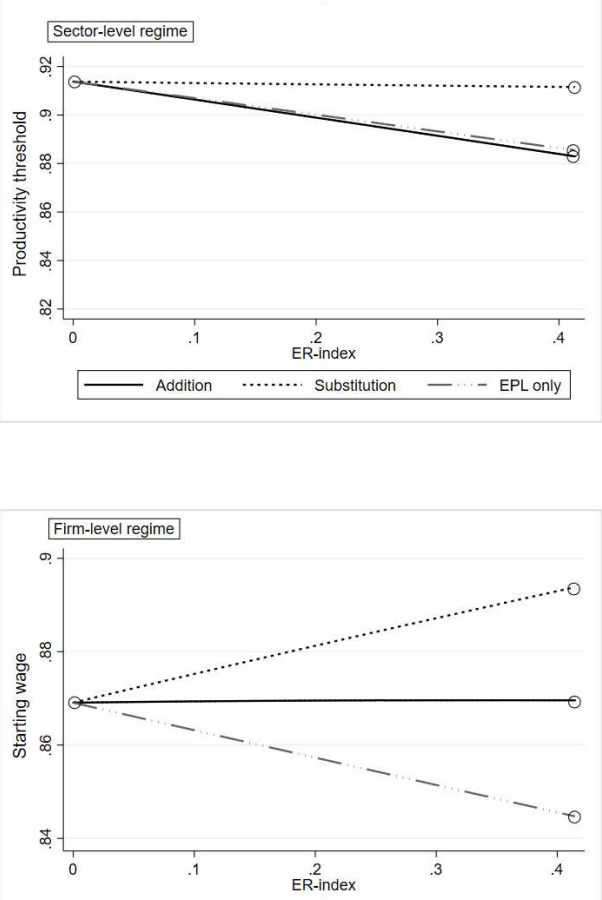

Sector-level regime

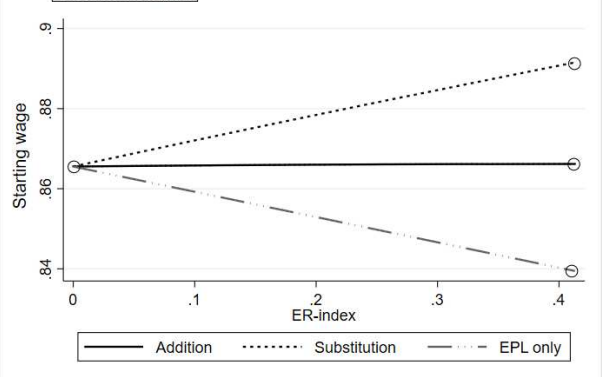



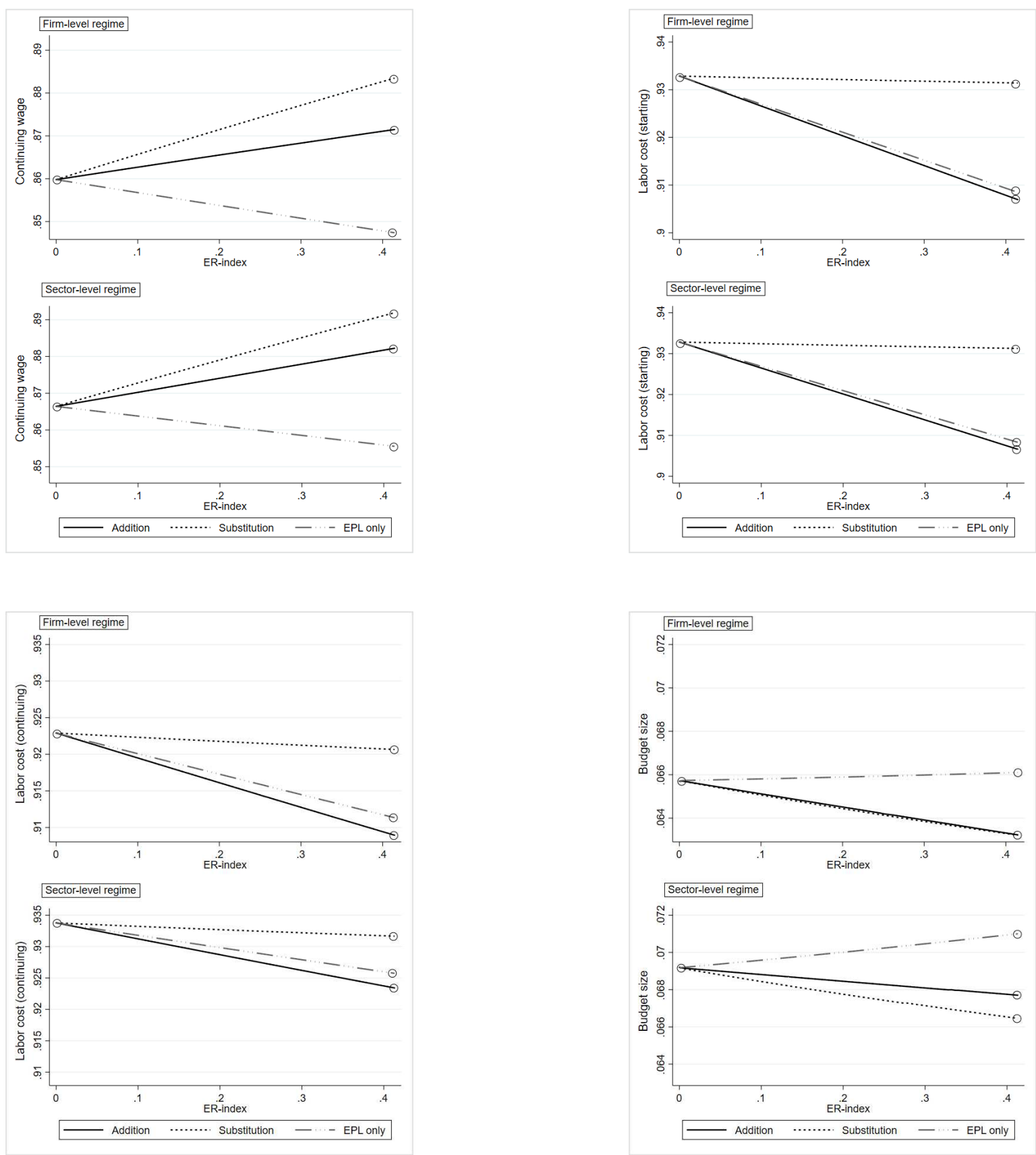

Table 8: Evolution of labor market outcomes according to the ER-index $=0.41$

\begin{tabular}{llrrrrrr}
\hline \multirow{2}{*}{ Variable } & Notation & \multicolumn{5}{c}{ Bargaining regime } \\
\cline { 3 - 7 } & & \multicolumn{3}{c}{ Sector-level } \\
\cline { 3 - 7 } & & Addition & Substitution & EPL only & Addition & Substitution & EPL only \\
\hline Unemployment rate (\%) & $u$ & -0.205 & $\mathbf{- 0 . 3 5 4}$ & 0.223 & $\mathbf{- 0 . 3 6 7}$ & -0.332 & 0.010 \\
Labor market tightness & $\theta$ & -0.011 & $\mathbf{0 . 0 4 3}$ & -0.056 & -0.010 & $\mathbf{0 . 0 4 1}$ & -0.052 \\
Productivity threshold & $\epsilon_{d}$ & $-\mathbf{0 . 0 3 1}$ & -0.002 & -0.028 & $\mathbf{- 0 . 0 4 6}$ & -0.003 & -0.043 \\
Average starting wage & $\bar{w}_{o}$ & 0.001 & $\mathbf{0 . 0 2 6}$ & -0.026 & 0.001 & $\mathbf{0 . 0 2 5}$ & -0.024 \\
Average continuing wage & $\bar{w}_{e}$ & 0.016 & $\mathbf{0 . 0 2 5}$ & -0.011 & 0.012 & $\mathbf{0 . 0 2 4}$ & -0.012 \\
Labor cost starting job & $(1+\tau) \overline{w_{o}}$ & $\mathbf{- 0 . 0 2 6}$ & -0.002 & -0.025 & $\mathbf{- 0 . 0 2 6}$ & -0.001 & -0.024 \\
Labor cost continuing job & $(1+\tau) \bar{w}_{e}$ & $\mathbf{- 0 . 0 1 0}$ & -0.002 & -0.008 & $\mathbf{- 0 . 0 1 4}$ & -0.002 & -0.012 \\
Budget (\%) & $B / Y$ & -0.147 & $\mathbf{- 0 . 2 7 1}$ & 0.183 & -0.250 & $\mathbf{- 0 . 2 5 2}$ & 0.037 \\
\hline
\end{tabular}




\subsection{Turbulence}

The differences between the two wage bargaining regimes stand out when there is more economic turbulence: a higher frequency of productivity shocks leads to more regularly renegotiated wages. The purpose here is to analyze the influence of turbulence on the effectiveness of reforms to demonstrate that the bargaining regime plays a major role in the success of ER implementation. Changing the frequency of productivity shocks is achieved by a change in $\delta$.

Table 9: Effects of ER reform in different turbulent economic environments

\begin{tabular}{|c|c|c|c|c|c|c|c|c|c|c|c|c|}
\hline \multirow[t]{3}{*}{ Variable } & \multirow[t]{3}{*}{ Notation } & & \multicolumn{10}{|c|}{ Abs. Change relative to pre-reform situation } \\
\hline & & & \multicolumn{5}{|c|}{ Sector-level } & \multicolumn{5}{|c|}{ Firm-level } \\
\hline & & & $\delta=0.005$ & $\delta=0.01$ & $\delta=0.0154$ & $\delta=0.02$ & $\delta=0.025$ & $\delta=0.005$ & $\delta=0.01$ & $\delta=0.0154$ & $\delta=0.02$ & $\delta=0.025$ \\
\hline Unemployment rate (\%) & $u$ & $\begin{array}{l}\text { addition } \\
\text { substitution } \\
\text { EPL only }\end{array}$ & $\begin{array}{l}-0.04 \\
-0.03 \\
-0.02\end{array}$ & $\begin{array}{r}-0.11 \\
-0.12 \\
0.03\end{array}$ & $\begin{array}{r}-0.21 \\
-0.35 \\
0.22\end{array}$ & $\begin{array}{r}-0.36 \\
-0.77 \\
0.74\end{array}$ & $\begin{array}{r}-0.67 \\
-1.87 \\
4.32\end{array}$ & $\begin{array}{l}-0.07 \\
-0.03 \\
-0.05\end{array}$ & $\begin{array}{l}-0.18 \\
-0.12 \\
-0.06\end{array}$ & $\begin{array}{r}-0.37 \\
-0.33 \\
0.01\end{array}$ & $\begin{array}{r}-0.61 \\
-0.69 \\
0.27\end{array}$ & $\begin{array}{r}-0.98 \\
-1.48 \\
2.05\end{array}$ \\
\hline Labor market tightness & $\theta$ & $\begin{array}{l}\text { addition } \\
\text { substitution } \\
\text { EPL only }\end{array}$ & $\begin{array}{r}-0.01 \\
0.01 \\
-0.02\end{array}$ & $\begin{array}{r}-0.01 \\
0.03 \\
-0.04\end{array}$ & $\begin{array}{r}-0.01 \\
0.04 \\
-0.06\end{array}$ & $\begin{array}{r}-0.01 \\
0.06 \\
-0.08\end{array}$ & $\begin{array}{r}0.00 \\
0.09 \\
-0.15\end{array}$ & $\begin{array}{r}-0.01 \\
0.01 \\
-0.02\end{array}$ & $\begin{array}{r}-0.01 \\
0.03 \\
-0.03\end{array}$ & $\begin{array}{r}-0.01 \\
0.04 \\
-0.05\end{array}$ & $\begin{array}{r}-0.01 \\
0.06 \\
-0.07\end{array}$ & $\begin{array}{r}0.00 \\
0.08 \\
-0.12\end{array}$ \\
\hline Productivity threshold & $\epsilon_{d}$ & $\begin{array}{l}\text { addition } \\
\text { substitution } \\
\text { EPL only }\end{array}$ & $\begin{array}{r}-0.02 \\
0.00 \\
-0.02\end{array}$ & $\begin{array}{r}-0.02 \\
0.00 \\
-0.02\end{array}$ & $\begin{array}{r}-0.03 \\
0.00 \\
-0.03\end{array}$ & $\begin{array}{r}-0.04 \\
0.00 \\
-0.03\end{array}$ & $\begin{array}{l}-0.05 \\
-0.01 \\
-0.03\end{array}$ & $\begin{array}{r}-0.03 \\
0.00 \\
-0.03\end{array}$ & $\begin{array}{r}-0.04 \\
0.00 \\
-0.03\end{array}$ & $\begin{array}{r}-0.05 \\
0.00 \\
-0.04\end{array}$ & $\begin{array}{l}-0.06 \\
-0.01 \\
-0.05\end{array}$ & $\begin{array}{l}-0.07 \\
-0.01 \\
-0.05\end{array}$ \\
\hline Average starting wage & $\overline{w_{o}}$ & $\begin{array}{l}\text { addition } \\
\text { substitution } \\
\text { EPL only }\end{array}$ & $\begin{array}{r}0.00 \\
0.01 \\
-0.01\end{array}$ & $\begin{array}{r}0.00 \\
0.02 \\
-0.02\end{array}$ & $\begin{array}{r}0.00 \\
0.03 \\
-0.03\end{array}$ & $\begin{array}{r}0.00 \\
0.04 \\
-0.04\end{array}$ & $\begin{array}{r}0.00 \\
0.05 \\
-0.07\end{array}$ & $\begin{array}{r}0.00 \\
0.01 \\
-0.01\end{array}$ & $\begin{array}{r}0.00 \\
0.02 \\
-0.02\end{array}$ & $\begin{array}{r}0.00 \\
0.02 \\
-0.02\end{array}$ & $\begin{array}{r}0.00 \\
0.03 \\
-0.03\end{array}$ & $\begin{array}{r}0.00 \\
0.05 \\
-0.06\end{array}$ \\
\hline Average continuing wage & $\overline{w_{e}}$ & $\begin{array}{l}\text { addition } \\
\text { substitution } \\
\text { EPL only }\end{array}$ & $\begin{array}{l}0.01 \\
0.01 \\
0.00\end{array}$ & $\begin{array}{l}0.01 \\
0.02 \\
0.00\end{array}$ & $\begin{array}{r}0.02 \\
0.03 \\
-0.01\end{array}$ & $\begin{array}{r}0.02 \\
0.03 \\
-0.02\end{array}$ & $\begin{array}{r}0.02 \\
0.05 \\
-0.05\end{array}$ & $\begin{array}{l}0.01 \\
0.01 \\
0.00\end{array}$ & $\begin{array}{r}0.01 \\
0.02 \\
-0.01\end{array}$ & $\begin{array}{r}0.01 \\
0.02 \\
-0.01\end{array}$ & $\begin{array}{r}0.01 \\
0.03 \\
-0.02\end{array}$ & $\begin{array}{r}0.02 \\
0.04 \\
-0.04\end{array}$ \\
\hline Labor cost (starting) & $(1+\tau) \overline{w_{o}}$ & $\begin{array}{l}\text { addition } \\
\text { substitution } \\
\text { EPL only }\end{array}$ & $\begin{array}{r}-0.01 \\
0.00 \\
-0.01\end{array}$ & $\begin{array}{r}-0.02 \\
0.00 \\
-0.02\end{array}$ & $\begin{array}{r}-0.03 \\
0.00 \\
-0.02\end{array}$ & $\begin{array}{r}-0.03 \\
0.00 \\
-0.03\end{array}$ & $\begin{array}{l}-0.05 \\
-0.01 \\
-0.03\end{array}$ & $\begin{array}{r}-0.01 \\
0.00 \\
-0.01\end{array}$ & $\begin{array}{r}-0.02 \\
0.00 \\
-0.02\end{array}$ & $\begin{array}{r}-0.03 \\
0.00 \\
-0.02\end{array}$ & $\begin{array}{r}-0.03 \\
0.00 \\
-0.03\end{array}$ & $\begin{array}{r}-0.04 \\
0.00 \\
-0.04\end{array}$ \\
\hline Labor cost (continuing) & $(1+\tau) \overline{w_{e}}$ & $\begin{array}{l}\text { addition } \\
\text { substitution } \\
\text { EPL only }\end{array}$ & $\begin{array}{l}0.00 \\
0.00 \\
0.00\end{array}$ & $\begin{array}{l}0.00 \\
0.00 \\
0.00\end{array}$ & $\begin{array}{r}-0.01 \\
0.00 \\
-0.01\end{array}$ & $\begin{array}{r}-0.02 \\
0.00 \\
-0.01\end{array}$ & $\begin{array}{l}-0.02 \\
-0.01 \\
-0.01\end{array}$ & $\begin{array}{l}0.00 \\
0.00 \\
0.00\end{array}$ & $\begin{array}{r}-0.01 \\
0.00 \\
-0.01\end{array}$ & $\begin{array}{r}-0.01 \\
0.00 \\
-0.01\end{array}$ & $\begin{array}{r}-0.02 \\
0.00 \\
-0.02\end{array}$ & $\begin{array}{l}-0.03 \\
-0.01 \\
-0.02\end{array}$ \\
\hline Budget (\%) & $B / Y$ & $\begin{array}{l}\text { addition } \\
\text { substitution } \\
\text { EPL only }\end{array}$ & $\begin{array}{l}-0.03 \\
-0.02 \\
-0.01\end{array}$ & $\begin{array}{r}-0.07 \\
-0.09 \\
0.02\end{array}$ & $\begin{array}{r}-0.15 \\
-0.27 \\
0.18\end{array}$ & $\begin{array}{r}-0.28 \\
-0.64 \\
0.64\end{array}$ & $\begin{array}{r}-0.58 \\
-1.70 \\
4.27\end{array}$ & $\begin{array}{l}-0.04 \\
-0.02 \\
-0.03\end{array}$ & $\begin{array}{l}-0.12 \\
-0.08 \\
-0.03\end{array}$ & $\begin{array}{r}-0.25 \\
-0.25 \\
0.04\end{array}$ & $\begin{array}{r}-0.44 \\
-0.56 \\
0.28\end{array}$ & $\begin{array}{r}-0.78 \\
-1.31 \\
2.01\end{array}$ \\
\hline
\end{tabular}

The observation of Table 9 yields 3 main results. Our analysis focuses on the evolution of the unemployment rate. First, the increase in turbulence leads to different results between the EPL-only scenario and the scenarios implementing ER. With the increase in turbulence, EPL-only is increasingly detrimental to employment. On the other hand, ER is all the more effective in terms of reducing unemployment when the frequency of shocks increases, regardless of the bargaining regime. Indeed, the increase in the frequency of shocks exacerbates the negative effect of the increase in separation costs on the expected profitability of a job. This is the only mechanism at play in the EPL-only scenario. In contrast, in the other scenarios, the ER results in a reduction in payroll tax, which in turn generates positive effects on employment. These effects are heightened as the frequency of shocks increases, since they allow for a larger reduction of the wage tax.

Second, the relative effectiveness of scenarios involving ER depends on the frequency of shocks. Indeed, during times of low turbulence, the addition scenario further reduces unemployment. However, when turbulence intensifies, the substitution scenario becomes more effective in combating unemployment. This result can be explained as follows. When shocks are infrequent in the economy the addition scenario results in lower unemployment, as in the EPL-only scenario. This decrease is simply the result of a combination of less job destruction (labor hoarding due to higher separation costs) and a small negative impact on job creation.

Third, the second result is verified more quickly in the sector-level regime than in the firm-level regime. Indeed, we notice that as soon as $\delta=0.01$, the substitution scenario is better than the addition scenario in the sector-level regime. In the firm-level regime, it is necessary to wait for an increased frequency of shocks $(\delta=0.02)$ to observe this result. In sum, the substitution scenario is more quickly effective when turbulence intensifies in the sector-level regime. 
Overall, reform design is an important factor in dealing with economic turbulence. Thus, in industries subject to many shocks, and in a sectoral bargaining regime, the substitution scenario is recommended. While in the industry subject to few shocks, the addition scenario gives better results.

\section{Conclusion}

Using an equilibrium unemployment model with frictions and endogenous destruction (Mortensen and Pissarides, 1994, 1999), we have highlighted the effect of employment protection reform based on the experiencerating U.S. system, depending on two wage bargaining regimes: a decentralized one at the firm level and a more centralized one at the sectoral level. Both negotiating regimes admit a Nash wage bargaining, but with different features. The firm-level bargaining regime allows for internal flexibility, with an individualized wage determination and no role for unions. The sector-level bargaining regime is characterized by a lack of internal flexibility, with a trade union that negotiates with an employer representation on a common wage applied to all firms in the sector. We have assessed the ER effects on labor market outcomes, considering 3 reform scenarios: (1) the ER tax funding UI is implemented without a review of the actual EPL (addition scenario). (2) the ER tax funding UI is implemented with a relaxation of the actual EPL (as advocated by Blanchard and Tirole (2003)) (substitution scenario). (3) no ER tax is implemented, only an increase in the existing EPL stringency ('EPL only' scenario).

With numerical exercises, we have confirmed findings in the existing literature demonstrating that an experiencerating system is effective in an economy where wage bargaining is decentralized. We have shown that ER is also effective when the negotiation is more centralized and takes place between an industry-wide union and an industry-wide employers' confederation. However, the effectiveness of the reform varies according to the scenario and the bargaining regime. The juxtaposition of the two systems seems more efficient in the firm-level bargaining economy through a downward wage adjustment that allows companies working in a turbulent economic environment to shift part of the increase in separation costs to workers. Thus, the experience-rating system combines the effects of increasing labor hoarding, without strong hiring disincentives. With regard to the level of sectoral negotiations, it is better to implement a reform that substitutes both systems. Indeed, following the reform, the industry's union manages to bargain higher wages by capturing the decline in the unemployment fiscal cost. This rigidity of wages benefits insiders, but reduces incentives for firms to create jobs in the addition scenario. This disincentive disappears in the substitution scenario.

Knowing that sectoral-level bargaining is still very important in Western European economies, introducing an ER system seems to be effective in terms of reducing unemployment. However, policy-makers must choose the right reform design by analyzing the economic environment of the country's main industries, in particular the level of economic turbulence they are facing.

Our work can be expanded on two main points: the modelling of collective bargaining and the analysis of ER implementation. On the first point, we have modelled a starting wage with the same characteristics under the two bargaining schemes. This assumption does not imply any structural difference in the job creation conditions, whereas we could imagine that starting wages in the sector-level bargaining regime are also collectively negotiated and thus would result in more rigid hiring wages that would change structurally the sector-level job creation condition. Moreover, we assume that a firm corresponds to a job and thus we only analyze the negotiation on wages and not on employment. We could model large firms and integrate negotiations on the level of employment. Moreover, we consider that the major difference between the two bargaining regimes is the flexibility degree of wages, due to a difference in the bargaining level. Yet, there are other characteristics to consider. For instance, unions' objectives, workers' bargaining power, or the level of coordination. Lastly, we have modelled two exclusive negotiation regimes, while in most economies company negotiations complement collective agreements at the sectoral level. On the second point, we assume that workers are homogeneous, implying similar separation costs and similar unemployment durations, but they could be different depending on the type of job contract or skill level. Lastly, our analysis is made at the steady state. It would be interesting to introduce macroeconomic shocks in order to dynamically highlight the differences in the adaptation of economies according to the bargaining regime following the ER's introduction. 


\section{Appendix A.1. Sensitivity analysis}

The difference between the two bargaining regimes lies on how continuing wages are negotiated. The continuing wage is set after a productivity shock. We then conduct a sensitivity analysis to the value of the productivity shock frequency $\delta$ of the labor market outcomes in the pre-reform situation. In Table A.10, we note that, although the frequency of shocks influences the values of labor outcomes, the difference between the two bargaining regimes is maintained.

Table A.10: Sensitivity analysis

\begin{tabular}{|c|c|c|c|c|c|c|c|}
\hline \multirow[t]{3}{*}{ Variable } & \multirow[t]{3}{*}{ Notation } & \multicolumn{6}{|c|}{ Bargaining regime } \\
\hline & & \multicolumn{3}{|c|}{ Sector-level } & \multicolumn{3}{|c|}{ Firm-level } \\
\hline & & $\delta=0.01$ & $\begin{array}{c}\delta=0.0154 \\
\text { (baseline) }\end{array}$ & $\delta=0.02$ & $\delta=0.01$ & $\begin{array}{c}\delta=0.0154 \\
\text { (baseline) }\end{array}$ & $\delta=0.02$ \\
\hline Unemployment rate (\%) & $u$ & 6.120 & 9.700 & 13.156 & 5.883 & 9.220 & 12.380 \\
\hline Labor market tightness & $\theta$ & 0.625 & 0.528 & 0.440 & 0.628 & 0.535 & 0.451 \\
\hline Productivity threshold & $\epsilon_{d}$ & 0.928 & 0.914 & 0.904 & 0.892 & 0.870 & 0.855 \\
\hline Job-finding rate & $\theta q(\theta)$ & 0.142 & 0.131 & 0.120 & 0.143 & 0.132 & 0.121 \\
\hline Separation rate & $\delta G\left(\epsilon_{d}\right)$ & 0.009 & 0.014 & 0.018 & 0.008 & 0.013 & 0.017 \\
\hline Average starting wage & $\overline{w_{o}}$ & 0.907 & 0.866 & 0.827 & 0.908 & 0.870 & 0.833 \\
\hline Average continuing wage & $\overline{w_{e}}$ & 0.906 & 0.866 & 0.829 & 0.899 & 0.860 & 0.824 \\
\hline Labor cost starting job & $(1+\tau) \overline{w_{o}}$ & 0.947 & 0.933 & 0.922 & 0.947 & 0.933 & 0.922 \\
\hline Labor cost continuing job & $(1+\tau) \overline{w_{e}}$ & 0.947 & 0.934 & 0.925 & 0.938 & 0.923 & 0.912 \\
\hline Budget (\%) & $B / Y$ & 4.170 & 6.920 & 9.810 & 4.000 & 6.573 & 9.200 \\
\hline
\end{tabular}

\section{Appendix A.2. Firm-level baseline with quarterly data from the U.S. economy}

We use the firm-level bargaining regime equilibrium as baseline for the calibration and test the different scenarios of reform (addition, substitution and EPL only) in order to assess whether the model is robust enough to replicate the same results than with the calibration using French data and the sector-level as a baseline. The calibration aims to fit data from the U.S. labor market and partially use the values from Pissarides (2009). Although the ER already exists in the U.S. economy and therefore testing its implementation may seem strange, the idea is simply to represent an economy considered as "flexible" in view of its labor market institutions.

The period is set to one quarter with a discount rate $r$ set to 0.004 . The $G$ distribution of specific productivity shocks is assumed to be uniform between $[0,1]$ and the new match productivity $\bar{\epsilon}$ is set to 1 . We use a Cobb-Douglas specification for the matching function, $m(u, v)=A u^{\alpha} v^{1-\alpha}$, which implies a job finding rate of $\theta q(\theta)=A(\theta)^{1-\alpha}$. $\alpha$ corresponds to the elasticity of the matching function and set at 0.5 as assumed in most of the literature (Petrongolo and Pissarides, 2001). The matching efficiency parameter $A^{32}$ set to 0.700 , the vacancy cost $\kappa$ set to 0.6321 and the productivity shock frequency $\delta$ set to 0.0268 are calibrated in order to target the following moments of the U.S economy: an unemployment rate of $4.00 \%$ (OECD), a labor market tightness of 0.72 (Pissarides, 2009) and a job-finding probability estimated at 0.594 (Pissarides, 2009). The value of the unemployment benefit $z$ is set to represent $50.00 \%$ of the average wage (the average replacement ratio in the U.S. (OECD). The set of costs implied in layoffs $c$ is arbitrary set to 1 with the sole objective of setting lower dismissal costs than in our calibration in France. The values are summarized in Table A.11.

\footnotetext{
${ }^{32} A=\frac{\theta q(\theta)}{\left(\theta^{*}\right)^{1-\alpha}}$ with $\theta q(\theta)=0.594$ the targeted value of job-finding rate and $\theta^{*}=0.72$ the targeted value of labor market tightness, we obtain: $A=0.700$.
} 
Table A.11: Parameters values (quarterly data) - Baseline: firm-level bargaining regime

\begin{tabular}{|c|c|c|c|c|c|c|}
\hline \multicolumn{2}{|c|}{ Labor Market Parameters Notation } & \multirow[t]{2}{*}{ Value } & \multirow[t]{2}{*}{ Calibration Targets } & \multirow[t]{2}{*}{ Notation } & \multirow[t]{2}{*}{ Value } & \multirow[t]{2}{*}{ Source } \\
\hline Baseline Parameters & & & & & & \\
\hline Matching efficiency & A & 0.7 & Unemployment rate & $u$ & 0.04 & OECD \\
\hline Elasticity of matching function & $\alpha$ & 0.5 & Labor market tightness & $\theta$ & 0.72 & Pissarides (2009) \\
\hline New match productivity & $\bar{\epsilon}$ & 1 & Job-finding rate & $\theta q(\theta)$ & 0.594 & Pissarides (2009) \\
\hline Interest rate & $r$ & 0.004 & & & & \\
\hline \multicolumn{7}{|l|}{ Calibrated Parameters } \\
\hline Vacancy cost & $\kappa$ & 0.6321 & & & & \\
\hline Productivity shock frequency & $\delta$ & 0.0268 & & & & \\
\hline Unemployment benefits & $z$ & 0.4637 & & & & \\
\hline \multicolumn{7}{|l|}{ Policy parameters } \\
\hline Firing cost & $c$ & 1 & & & & \\
\hline Experience rating index & $\rho$ & 0 & & & & \\
\hline
\end{tabular}

Table A.12: Pre-reform position

\begin{tabular}{llll}
\hline Variable & Notation & \multicolumn{2}{l}{ Bargaining regime } \\
\cline { 3 - 4 } & & Sector-level (baseline) & Firm-level \\
\hline Unemployment rate (\%) & $u$ & 4.110 & 4.000 \\
Labor market tightness & $\theta$ & $\mathbf{0 . 7 1 9}$ & $\mathbf{0 . 7 2 0}$ \\
Productivity threshold & $\epsilon_{d}$ & $\mathbf{0 . 9 4 8}$ & $\mathbf{0 . 9 2 2}$ \\
Average starting wage & $\overline{w_{o}}$ & $\mathbf{0 . 9 3 1}$ & $\mathbf{0 . 9 3 1}$ \\
Average continuing wage & $\overline{w_{e}}$ & $\mathbf{0 . 9 3 3}$ & $\mathbf{0 . 9 2 7}$ \\
Labor cost starting job & $\overline{w_{o}}(1+\tau)$ & $\mathbf{0 . 9 5 1}$ & $\mathbf{0 . 9 5 1}$ \\
Labor cost continuing job & $\overline{w_{e}}(1+\tau)$ & $\mathbf{0 . 9 5 3}$ & $\mathbf{0 . 9 4 7}$ \\
Payroll tax & $\tau$ & $\mathbf{0 . 0 2 1}$ & $\mathbf{0 . 0 2 1}$ \\
Budget (\%) & $B / Y$ & $\mathbf{2 . 0 1 0}$ & $\mathbf{1 . 9 7 5}$ \\
Experience-rating tax index & $\rho$ & $\mathbf{0 . 0 0 0}$ & $\mathbf{0 . 0 0 0}$ \\
\hline
\end{tabular}

Table A.13: Evolution of labor market outcomes according to the ER-index $=0.41$

\begin{tabular}{|c|c|c|c|c|c|c|c|}
\hline \multirow[t]{3}{*}{ Variable } & \multirow[t]{3}{*}{ Notation } & \multicolumn{6}{|c|}{ Bargaining regime } \\
\hline & & \multicolumn{3}{|c|}{ Sector-level } & \multicolumn{3}{|c|}{ Firm-level } \\
\hline & & Addition & Substitution & EPL only & Addition & Substitution & EPL only \\
\hline Unemployment rate (\%) & $u$ & -0.011 & -0.020 & 0.007 & -0.025 & -0.018 & -0.009 \\
\hline Labor market tightness & $\theta$ & -0.006 & 0.006 & -0.012 & -0.006 & 0.006 & -0.012 \\
\hline Productivity threshold & $\epsilon_{d}$ & -0.006 & 0.000 & -0.006 & -0.010 & 0.000 & -0.009 \\
\hline Average starting wage & $\overline{w_{o}}$ & 0.000 & 0.008 & -0.008 & 0.000 & 0.008 & -0.008 \\
\hline Average continuing wage & $\overline{w_{e}}$ & 0.003 & 0.008 & -0.005 & 0.002 & 0.008 & -0.005 \\
\hline Labor cost starting job & $(1+\tau) \overline{w_{o}}$ & -0.008 & 0.000 & -0.008 & -0.008 & 0.000 & -0.008 \\
\hline Labor cost continuing job & $(1+\tau) \overline{w_{e}}$ & -0.005 & 0.000 & -0.005 & -0.006 & 0.000 & -0.005 \\
\hline Budget (\%) & $B / Y$ & -0.005 & -0.010 & 0.004 & -0.012 & -0.008 & -0.003 \\
\hline
\end{tabular}

Note: The values are the absolute change relative to the pre-reform position (in percentage points for the unemployment rate and the budget). For the EPL only scenario, we consider an increase of 0.32 of $c$. For the substitution scenario, an ER-index equal to 0.41 corresponds to a substitution of $32 \%$ of $c$ by $\phi$.

Table A.12 show that labor market outcomes in the pre-reform position are sensitive to the frequency of shocks $\delta$, but the difference between the firm-level regime and the sector-level one is the same as in our numerical analysis with the sector-level in baseline. Table A.13 shows that the effects of ER implementation go in the similar direction as in our numerical exercise with sector-level as baseline and with French data. This confirms that the direction of effects of ER implementation according to reform design and negotiation regime are not sensitive to the value of the parameters. 


\section{References}

Aidt, T. and Tzannatos, Z. (2002), 'Unions and collective bargaining', Economic Effects in a Global Environment. Washington DC: Weltbank.

Albertini, J. (2011), 'Unemployment insurance payroll tax, matching frictions and the labor market dynamics', University of Evry, Mimeo .

Albertini, J. and Fairise, X. (2013a), 'Search frictions, real wage rigidities and the optimal design of unemployment insurance', Journal of Economic Dynamics and Control 37(9), 1796-1813.

Albertini, J. and Fairise, X. (2013b), 'Search frictions, real wage rigidities and the optimal design of unemployment insurance', Journal of Economic Dynamics and Control 37(9), 1796-1813.

Albrecht, J. W. and Vroman, S. B. (1999), 'Unemployment compensation finance and efficiency wages', Journal of Labor Economics 17(1), 141-167.

Anderson, P. M. and Meyer, B. D. (1994), The effects of unemployment insurance taxes and benefits on layoffs using firm and individual data, Technical report, National Bureau of Economic Research.

Anderson, P. M. and Meyer, B. D. (2000), 'The effects of the unemployment insurance payroll tax on wages, employment, claims and denials', Journal of Public Economics 78(1-2), 81-106.

Andolfatto, D., Contrepois, S. and Collectif (2016), Syndicats et dialogue social, P.I.E. Peter Lang.

Bassanini, A. and Garnero, A. (2013), 'Dismissal protection and worker flows in oecd countries: Evidence from crosscountry/cross-industry data', Labour Economics 21, 25-41.

Baumann, F. and Stähler, N. (2008), 'Union power as a reason for europe not to introduce experience rating?', Journal of Institutional and Theoretical Economics JITE 164(3), 568-585.

Belot, M. and Van Ours, J. C. (2004), 'Does the recent success of some oecd countries in lowering their unemployment rates lie in the clever design of their labor market reforms?', Oxford Economic Papers 56(4), 621-642.

Bertola, G. and Rogerson, R. (1997), 'Institutions and labor reallocation', European Economic Review 41, 1147-1171.

Blanchard, O. and Portugal, P. (2001), 'What hides behind an unemployment rate: comparing portuguese and US labor markets', American Economic Review pp. 187-207.

Blanchard, O. and Tirole, J. (2003), Protection de l'emploi et procédures de licenciement, La documentation française.

Blanchard, O. and Tirole, J. (2008), 'The joint design of unemployment insurance and employment protection: a first pass', Journal of the European Economic Association 6(1), 45-77.

Boeri, T. (2010), 'Institutional reforms in european labour markets', Handbook of Labour Economics 4, $1173-236$.

Boeri, T. (2014), Two-tier bargaining, Technical report, IZA Discussion Papers.

Boeri, T. (2015), 'Perverse effects of two-tier wage bargaining structures', IZA World of Labor .

Boeri, T. and Burda, M. C. (2009), 'Preferences for collective versus individualised wage setting', Economic Journal 119(540), 1440-1463.

Boeri, T. and Garibaldi, P. (2009), 'Beyond eurosclerosis', Economic Policy 24(59), 409-461.

Boeri, T. and Van Ours, J. (2013), The economics of imperfect labor markets, second edition edn, Princeton University Press.

Burda, M. C. (1992), 'A note on firing costs and severance benefits in equilibrium unemployment', Scandinavian Journal of Economics 94(3), 479-489.

Cahuc, P. (2014), 'Search, flows, job creations and destructions', Labour Economics 30, 22-29.

Cahuc, P. and Malherbet, F. (2001), 'Faut-il moduler les cotisations patronales à l'assurance chômage?', Revue économique 52(3), 695-703. 
Cahuc, P. and Malherbet, F. (2004), 'Unemployment compensation finance and labor market rigidity', Journal of Public Economics 88(3), 481-501.

Cahuc, P., Zylberberg, A. and Carcillo, S. (2014), Labor economics, MIT press.

Calmfors, L. and Driffill, J. (1988), 'Bargaining structure, corporatism and macroeconomic performance', Economic Policy 3(6), 13-61.

Cazes, S. and Nesporova, A. (2003), Employment protection legislation (epl) and its effects on labour market performance, in 'ILO Conference Paper'.

Charlot, O. and Malherbet, F. (2010), 'Réforme de la protection de l'emploi et inégalités face au chômage dans un modèle d'appariement', Recherches économiques de Louvain 76(1), 57-112.

Clark, A. and Postel-Vinay, F. (2009), 'Job security and job protection', Oxford Economic Papers 61(2), 207-239.

Delacroix, A. (2006), 'A multisectorial matching model of unions', Journal of Monetary Economics 53(3), 573-596.

Driffill, J. (2006), 'The centralization of wage bargaining revisited: what have we learnt?', JCMS: Journal of Common Market Studies 44(4), 731-756.

Druant, M., Fabiani, S., Kezdi, G., Lamo, A., Martins, F. and Sabbatini, R. (2012), 'Firms' price and wage adjustment in europe: Survey evidence on nominal stickiness', Labour Economics 19(5), 772-782.

European Commission (2004), Employment in Europe, Office for official publications of the European Communities.

Fath, J. and Fuest, C. (2005a), 'Experience rating of unemployment insurance in the us: A model for europe?', CESifo DICE Report 3(2), 45-50.

Fath, J. and Fuest, C. (2005b), 'Experience rating versus employment protection laws in a model where firms monitor workers', Scandinavian Journal of Economics 107(2), 299-314.

Fath, J. and Fuest, C. (2005c), 'Temporary layoffs and unemployment insurance: Is experience rating desirable?', German Economic Review 6(4), 471-483.

Feldstein, M. (1976), 'Temporary layoffs in the theory of unemployment', Journal of Political Economy 84(5), 937-957.

German Council of Economic Experts (2003), Staatsfinanzen konsolidieren - Steuersystem reformieren, Elsevier Group: Reutlingen.

Gnocchi, S., Lagerborg, A. and Pappa, E. (2015), 'Do labor market institutions matter for business cycles?', Journal of Economic Dynamics and Control 51, 299-317.

Hairault, J.-O., Le Barbanchon, T. and Sopraseuth, T. (2015), 'The cyclicality of the separation and job finding rates in france', European Economic Review 76, 60-84.

Hall, R. E. and Milgrom, P. R. (2008), 'The limited influence of unemployment on the wage bargain', American Economic Review 98(4), 1653-1674.

Izquierdo, M., Jimeno, J. F., Kosma, T., Lamo, A., Millard, S., Rõõm, T. and Viviano, E. (2017), Labour market adjustment in europe during the crisis: Microeconomic evidence from the wage dynamics network survey, Technical report, ECB Occasional Paper.

Jimeno, J. F. and Thomas, C. (2013), 'Collective bargaining, firm heterogeneity and unemployment', European Economic Review 59, 63-79.

Kramarz, F. and Michaud, M.-L. (2010), 'The shape of hiring and separation costs in france', Labour Economics 17(1), 27-37.

Lazear, E. P. (1990), 'Job security provisions and employment', Quarterly Journal of Economics 105(3), 699-726.

L'Haridon, O. and Malherbet, F. (2009), 'Employment protection reform in search economies', European Economic Review 53(3), 255-273. 
L'Haridon, O. and Malherbet, F. (2010), 'Réforme de la protection de l'emploi et performance du marché du travail dans un modèle d'appariement', Annals of Economics and Statistics/Annales d'Économie et de Statistique pp. 247-284.

Margolis, D. and Fougère, D. (2000), 'Moduler les cotisations employeurs à l'assurance-chômage: les expériences de bonusmalus aux etats-unis', Revue française d'économie 15(2), 3-76.

Martin, J. P. and Scarpetta, S. (2012), 'Setting it right: employment protection, labour reallocation and productivity', De Economist 160(2), 89-116.

Martins, P. S. (2014), 30,000 minimum wages: The economic effects of collective bargaining extensions, Technical report, Institute for the Study of Labor (IZA).

Mongrain, S. and Roberts, J. (2005), 'Unemployment insurance and experience rating: Insurance versus efficiency', International Economic Review 46(4), 1303-1319.

Mortensen, D. T. and Pissarides, C. A. (1994), 'Job creation and job destruction in the theory of unemployment', Review of Economic Studies 61(3), 397-415.

Mortensen, D. T. and Pissarides, C. A. (1999), 'New developments in models of search in the labor market', Handbook of Labor Economics 3, 2567-2627.

Nickell, S. and Layard, R. (1999), 'Labor market institutions and economic performance', Handbook of Labor Economics 3, 30293084.

Nickell, S., Nunziata, L. and Ochel, W. (2005), 'Unemployment in the oecd since the 1960s. what do we know?', Economic Journal 115(500), 1-27.

OECD (1997), OECD Employment Outlook, OECD Publishing.

OECD (2004), OECD Employment Outlook, OECD Publishing.

OECD (2013), OECD Employment Outlook, OECD Publishing.

OECD (2015), 'Graph 4.6. net replacement rates of unemployment benefits in oecd countries'.

URL: /content/graph/9789264233454-graph34-en

OECD (2016), OECD Employment Outlook, OECD Publishing.

OECD (2018), OECD Employment Outlook, OECD publishing.

Petrongolo, B. and Pissarides, C. A. (2001), 'Looking into the black box: A survey of the matching function', Journal of Economic Literature 39(2), 390-431.

Pissarides, C. A. (2000), Equilibrium unemployment theory, MIT press.

Pissarides, C. A. (2009), 'The unemployment volatility puzzle: Is wage stickiness the answer?', Econometrica 77(5), 1339-1369.

Postel-Vinay, F. and Saint-Martin, A. (2004), 'Comment les salariés perçoivent-ils la protection de l'emploi?', Economie et Statistique 372(1), 41-59.

Ratner, D. (2013), Unemployment insurance experience rating and labor market dynamics, Technical report, Board of Governors of the Federal Reserve System (US).

Rogerson, R., Shimer, R. and Wright, R. (2005), 'Search-theoretic models of the labor market: A survey', Journal of Economic Literature 43(4), 959-988.

Ronchi, M. and di Mauro, F. (2017), Wage bargaining regimes and firms' adjustments to the great recession, Technical report, European Central Bank.

Rycx, F. (2003), 'Industry wage differentials and the bargaining regime in a corporatist country', International Journal of Manpower 24(4), 347-366.

Shimer, R. (2004), 'The consequences of rigid wages in search models', Journal of the European Economic Association 2(23), 469-479. 
Shimer, R. (2005), 'The cyclical behavior of equilibrium unemployment and vacancies', American Economic Review 95(1), 2549.

Terraz, I. and Jaoul-Grammare, M. (2012), 'Diversité et évolution de la syndicalisation en europe', Bulletin de l'Observatoire des Politiques Economiques en Europe 15(34), 6.

Topel, R. H. (1983), 'On layoffs and unemployment insurance’, American Economic Review 73(4), 541-559.

Visser, J. (2013), Wage bargaining institutions-from crisis to crisis, Technical report, Directorate General Economic and Financial Affairs (DG ECFIN), European Commission.

Visser, J. (2016), 'What happened to collective bargaining during the great recession?', IZA Journal of Labor Policy 5(1), 9.

Woodbury, S. A., Anderson, R. and Jacobson, L. (2004), 'Layoffs and experience rating of the unemployment insurance payroll tax: Panel data analysis of employers in three states', Policy report, US Department of Labor .

Zweimüller, J. and Barth, E. (1994), 'Bargaining structure, wage determination, and wage dispersion in 6 oecd countries', Kyklos 47(1), 81-93. 